\title{
Synthesis, DNA Binding, and Molecular Docking Studies of Dimethylaminobenzaldehyde-Based Bioactive Schiff Bases
}

\author{
Zainab M. Almarhoon $\left(\mathbb{D}^{1},{ }^{1}\right.$ Wedad A. Al-Onazi $\left(\mathbb{D},{ }^{1}\right.$ Asma A. Alothman $\left(D^{1}{ }^{1}\right.$ \\ Amal M. Al-Mohaimeed ${ }^{1},{ }^{1}$ and Eida S. Al-Farraj ${ }^{2}$ \\ ${ }^{1}$ Department of Chemistry, College of Science, King Saud University, P.O. Box 22452, Riyadh 11495, Saudi Arabia \\ ${ }^{2}$ Department of Chemistry, College of Science, Imam Mohammad Ibn Saud Islamic University (IMSIU), \\ Riyadh 13623, Saudi Arabia \\ Correspondence should be addressed to Zainab M. Almarhoon; zalmarhoon@ksu.edu.sa
}

Received 23 November 2018; Revised 7 May 2019; Accepted 9 June 2019; Published 1 July 2019

Academic Editor: Artur M. S. Silva

Copyright (C) 2019 Zainab M. Almarhoon et al. This is an open access article distributed under the Creative Commons Attribution License, which permits unrestricted use, distribution, and reproduction in any medium, provided the original work is properly cited.

\begin{abstract}
A new series of $p$-dimethylaminobenzaldehyde derivatives were tested for therapeutic potential by exploring their properties through characterization. The derivatives were synthesized by $1: 1$ condensation reaction of $p$-dimethylaminobenzaldehyde and substituted amines. The synthesized compounds 1-8 were characterized by different characterization techniques including IR, mass, ${ }^{1} \mathrm{H}$ NMR, and ${ }^{13} \mathrm{C}$ NMR spectroscopy, elemental analysis, and mass spectrometry. Furthermore, binding of these Schiff bases to Ct-DNA was examined by absorption spectroscopy, fluorescence quenching, circular dichroic, viscosity measurement, molecular docking, and molecular dynamics simulation methods. Schiff bases were tested for antimicrobial activity against bacterial species Escherichia coli, Klebsiella pneumoniae, Pseudomonas aeruginosa, and Staphylococcus aureus by the disc diffusion method. The pharmacological treatment of Schiff bases showed that 1-8 have promising potential against tested bacterial strains. The molecular docking study of the target compounds was also carried out against B-DNA dodecamer d(CGCGAATTCGCG) and it has been found that 1-8 can bind to Ct-DNA via an intercalative mode. DPPH free radical and hydrogen peroxide scavenging assays were employed to assess the antioxidant potential of synthesized Schiff bases.
\end{abstract}

\section{Introduction}

Heterocyclic Schiff base chemistry is one of the attractive and challenging fields in current medical science. Due to expanded range of applications, medicinal chemistry has grown actively into the most active research area. Heterocyclic Schiff base derivatives are the most extensively used organic compounds with broad range of applications used as pigments, dyes, catalysts, and intermediates in many organic reactions $[1,2]$. They showed phototropism and thermochromism in the solid state used in optical and electrochemical sensors for the detection and enhancement of selectivity and sensitivity $[3,4]$. Due to their applications in biological, analytical, and medicinal field, and their role as catalysts in organic synthesis, heterocyclic Schiff bases are considered as one of the most potential groups of heterocyclic compounds [5]. The presence of azomethine group in heterocyclic Schiff base derivatives makes it very critical for various biological applications such as antifungal $[6,7]$, antibacterial [8, 9], antiproliferative [10], anticoagulant [11], anti-inflammatory [12], and antiviral [13] agents. They have been widely used in coordination chemistry mainly due to their facile synthesis, electronic properties, and good solubility in common solvents [14].

Heterocyclic tridentate Schiff base ligands, with a flexible atom, are better in comparison with bidentate ligand, and their chelating power makes them suitable ligands for stabilizing transition metals in various oxidation states and in wide range of catalytic transformations. They have been used extensively in biochemistry, material science, hydrometallurgy, catalysis and separation phenomena, and many of the biological processes $[15,16]$. Due to their thermal stability, 
biological applications, and presence of nitrogen atom in aromatic ring, pyridine and pyrimidine-based heterocyclic compounds are considered to be better ligands [17].

Since DNA and genetic material contain all cellular information, the study of DNA interaction is a very important aspect at present. Interaction of small molecules with DNA has been investigated and it attracted more attention for the designing of more effective drugs which target to DNA. Classical and nonclassical intercalation and groove or electrostatic modes of binding have been studied by various interaction modes of drug-DNA [18-22]. Free radicals were mostly generated in various bio-oxidative processes that damage various body components such as fat and proteins and cause various harmful diseases such as cancer, hypertension, Parkinson's disease, and Alzheimer's disease. Therefore, to develop new therapeutic drugs to neutralize the effect or damage caused by free radicals is to achieve more attention [23-26].

In literature, an antioxidant activity evaluation of heterogeneous ring derivatives using hydrogen peroxide and $\mathrm{DPPH}$ radicals was reported free in various ways and many of these compounds act as good antioxidants. Thus, to know how these antioxidant compounds work is very essential [27]. Diseases spread by bacteria are most common, and the mortality rate associated with bacterial infections increases day by day. Lack of medicinal treatment is the prime cause related to bacterial infections due to the resistance of bacteria to antibiotics. Therefore, it is a special need to develop new antimicrobial agents. Hence, researchers have been working for last many years to find new antibacterial agents due to the development of bacterial resistance [28].

So in this regard, we have tried to develop such types of heterocyclic derivatives which can bind easily with DNA and significant antioxidant to prevent damage caused by free radicals [29]; herein, we reported synthesis of unknown $p$ dimethylaminobenzaldehyde derivatives 1-8 and screened their DNA binding, fluorescence quenching, and antioxidant and antimicrobial assays. In addition, in this work, we calculated some molecular docking parameters of compounds in order to correlate them with their antimicrobial activity.

\section{Experimental Section}

2.1. Synthesis of p-Dimethylaminobenzaldehyde Derivatives (1-8). The compounds were synthesized according to the given protocol $[30,31]$. An appropriate amount of corresponding amines $(10 \mathrm{mmol})$ in $20 \mathrm{~mL}$ ethanol was slowly added to a solution of $p$-dimethylaminobenzaldehyde $(10 \mathrm{mmol})$ in $20 \mathrm{~mL}$ ethanol. Few drops of concentrated $\mathrm{H}_{2} \mathrm{SO}_{4}$ were added to the above mixture. The corresponding coloured solutions were refluxed at constant stirring for $\sim 7 \mathrm{~h}$. After completion of reaction, the contents of the flask were poured into ice-cold water. The coloured precipitates were filtered off by Buchner funnel and finally dried over fused $\mathrm{CaCl}_{2}$ and recrystallized in ethanol.

2.1.1. 5-(Dimethylamino)-6-((4-(dimethylamino)benzylidene)amino)pyridine-2,4-dicarbonitrile (1). Yellow solid. Yield $73 \%$, mp $238^{\circ} \mathrm{C}$. IR spectrum, $v, \mathrm{~cm}^{-1}: 1574(\mathrm{HC}=\mathrm{N})$,
$2213(-\mathrm{C} \equiv \mathrm{N}) .{ }^{1} \mathrm{H}$ NMR $\left(300 \mathrm{MHz}, \mathrm{DMSO}-\mathrm{d}_{6}\right) \delta$ in ppm: 6.67-7.67 (m, 5H, Ar-H), 8.67 (s, 1H, $-\mathrm{CH}=\mathrm{N}), 3.13(\mathrm{~s}, 12 \mathrm{H}$, $\left.-\mathrm{N}-\mathrm{CH}_{3}\right) .{ }^{13} \mathrm{C} \mathrm{NMR}\left(100 \mathrm{MHz}, \mathrm{DMSO}-\mathrm{d}_{6}\right) \delta$ in ppm: 160.77 , 154.68, 148.29, 140.20, 131.99, 125.24, 121.83, 118.97, 117.27, 112.76, 40.81; MS $(\mathrm{m} / z)$ : $318.40\left(\mathrm{M}^{+}\right)$. Anal. calc. for $\mathrm{C}_{18} \mathrm{H}_{18} \mathrm{~N}_{6}$ (\%): C 67.90; H 5.70; N 26.4. Found: C 67.37; H $5.62 ; \mathrm{N} 26.33$.

2.1.2. (E)-2-((4-(Dimethylamino)benzylidene)amino)-6-(pyrrolidin-1-yl)pyridine-3,5-dicarbonitrile (2). Brown solid. Yield $65 \%, \mathrm{mp} 214^{\circ} \mathrm{C}$. IR spectrum, $v, \mathrm{~cm}^{-1}: 1572(-\mathrm{HC}=\mathrm{N}), 2212$ $(-\mathrm{C} \equiv \mathrm{N}) .{ }^{1} \mathrm{H}$ NMR $\left(300 \mathrm{MHz}, \mathrm{DMSO}-\mathrm{d}_{6}\right) \delta$ in ppm: 6.66-8.51 $(\mathrm{m}, 5 \mathrm{H}, \mathrm{Ar}-\mathrm{H}), 8.85(\mathrm{~s}, 1 \mathrm{H},-\mathrm{CH}=\mathrm{N}), 3.12\left(\mathrm{~s}, 12 \mathrm{H},-\mathrm{N}-\mathrm{CH}_{3}\right)$, 3.47 (s, 4H, -N-CH $\left.-_{\text {cyclopentane }}\right), \quad 1.96$ (s, 4H, $\left.-\mathrm{CH}_{2}-{ }_{\text {cyclopentane }}\right){ }^{13} \mathrm{C} \mathrm{NMR}\left(100 \mathrm{MHz}, \mathrm{DMSO}-\mathrm{d}_{6}\right) \delta$ in ppm: 161.54, 155.11, 148.29, 142.90, 133.02, 127.61, 125.58, $118.74,117.23,115.84,53.47,40.73,25.68$; MS $(m / z): 344.4$ $\left(\mathrm{M}^{+}\right)$. Anal. calc. for $\mathrm{C}_{20} \mathrm{H}_{20} \mathrm{~N}_{6}(\%)$ : C, 69.75; H, 5.85; N, 24.40. Found: C, 69.67; H, 5.79; N, 24.32.

2.1.3. (E)-2-((4-(Dimethylamino)benzylidene)amino)-4-phenyl-6-(pyrrolidin-1-yl)pyridine-3,5-dicarbonitrile (3). Yellow solid. Yield $69 \%, \mathrm{mp} 264^{\circ} \mathrm{C}$. IR spectrum, $v, \mathrm{~cm}^{-1}: 1592$ $(-\mathrm{HC}=\mathrm{N}), 2210(-\mathrm{C} \equiv \mathrm{N}) .{ }^{1} \mathrm{H}$ NMR $\left(300 \mathrm{MHz}, \mathrm{DMSO}-\mathrm{d}_{6}\right) \delta$ in ppm: 6.95-8.04 (m, 9H, Ar-H), $9.72(\mathrm{~s}, 1 \mathrm{H},-\mathrm{CH}=\mathrm{N}), 3.48$ (s, $4 \mathrm{H},-\mathrm{N}-\mathrm{CH}_{2}-$ cyclopentane) 1.97 (s, $4 \mathrm{H},-\mathrm{CH}_{2}-$ cyclopentane), $3.01\left(\mathrm{~s}, 6 \mathrm{H},-\mathrm{N}-\mathrm{CH}_{3}\right) .{ }^{13} \mathrm{C} \mathrm{NMR}\left(100 \mathrm{MHz}, \mathrm{DMSO}-\mathrm{d}_{6}\right) \delta$ in ppm: 177.25, 162.59, 155.10, 148.29, 142.90, 133.04, 131.98, $127.62,125.59,124.97,111.51,53.47,40.79,25.47$; MS $(\mathrm{m} / z)$ : $420.5\left(\mathrm{M}^{+}\right)$. Anal. calc. for $\mathrm{C}_{26} \mathrm{H}_{24} \mathrm{~N}_{6}(\%)$ : C, 74.26; H, 5.75; N, 19.99. Found: C, 74.12; H, 5.68; N, 19.74.

2.1.4. (E)-2-((4-(Dimethylamino)benzylidene)amino)-6-(piperidin-1-yl)pyridine-3,5-dicarbonitrile (4). Brown solid. Yield $69 \%, \mathrm{mp} 226^{\circ} \mathrm{C}$. IR spectrum, $v, \mathrm{~cm}^{-1}$ : $1598(-\mathrm{HC}=\mathrm{N}), 2200$ $(-\mathrm{C} \equiv \mathrm{N}) .{ }^{1} \mathrm{H}$ NMR $\left(300 \mathrm{MHz}, \mathrm{DMSO}-\mathrm{d}_{6}\right) \delta$ in ppm: 6.85-8.10 (m, 5H, Ar-H), 8.95 (s, 1H, $-\mathrm{CH}=\mathrm{N}-), 3.28$ (s, 2H,-CHcyclohexane), $3.03\left(\mathrm{~s}, 6 \mathrm{H},-\mathrm{N}-\mathrm{CH}_{3}\right), 11.45(\mathrm{~s}, 1 \mathrm{H},-\mathrm{OH}), 1.84$ (s, $8 \mathrm{H},-\mathrm{CH}_{2}-$ cyclohexane $) .{ }^{13} \mathrm{C}$ NMR $\left(100 \mathrm{MHz}, \mathrm{DMSO}-\mathrm{d}_{6}\right) \delta$ in ppm: 160.25, 151.21, 148.49, 138.72, 134.77, 133.18, 129.81, 128.36, 123.86, 122.71, 119.73, 40.82; MS $(\mathrm{m} / z)$ : $358.4\left(\mathrm{M}^{+}\right)$. Anal. calc. for $\mathrm{C}_{21} \mathrm{H}_{22} \mathrm{~N}_{6}$. (\%): C, 70.33; H, 6.19; N, 23.45. Found: C, 70.29; H, 6.13; N, 23.42.

2.1.5. (E)-2-((4-(Dimethylamino)benzylidene)amino)-4-phenyl6-(piperidin-1-yl)pyridine-3,5-dicarbonitrile (5). Orange solid. Yield $74 \%, \mathrm{mp} 276^{\circ} \mathrm{C}$. IR spectrum, $v, \mathrm{~cm}^{-1}: 1557(-\mathrm{HC}=\mathrm{N})$, $2208(-\mathrm{C} \equiv \mathrm{N}) .{ }^{1} \mathrm{H}$ NMR $\left(300 \mathrm{MHz}, \mathrm{DMSO}-\mathrm{d}_{6}\right) \delta$ in ppm: 6.65-8.03 (m, 9H, Ar-H), $8.65(\mathrm{~s}, 1 \mathrm{H},-\mathrm{CH}=\mathrm{N}), 3.28(\mathrm{~s}$, $\left.2 \mathrm{H},-\mathrm{CH}-_{\text {cyclohexane }}\right), \quad 3.08\left(\mathrm{~s}, 6 \mathrm{H},-\mathrm{N}-\mathrm{CH}_{3}\right), 1.82$ (s, $8 \mathrm{H},-\mathrm{CH}_{2}-$ cyclohexane $) .{ }^{13} \mathrm{C} \mathrm{NMR}\left(100 \mathrm{MHz}, \mathrm{DMSO}-\mathrm{d}_{6}\right) \delta$ in ppm: $163.21,158.75,148.29,142.85,133.04,131.98,127.62$, 119.02, 40.79; MS $(\mathrm{m} / z)$ : $434.5\left(\mathrm{M}^{+}\right)$. Anal. calc. for $\mathrm{C}_{27} \mathrm{H}_{26} \mathrm{~N}_{6}$ (\%): C, 74.63; H, 6.03; N, 19.34. Found: C, 74.58; $\mathrm{H}, 5.97 ; \mathrm{N}, 19.31$. 
2.1.6. (E)-4-(((5-Chloro-6-((2-(4-(pyrimidin-5-yloxy)phenyl)$1 \mathrm{H}$-pyrrol-1-yl)methyl)pyridin-2-yl)imino)methyl)-N,Ndimethylaniline (6). Pale yellow solid. Yield $64 \%, \mathrm{mp} 246^{\circ} \mathrm{C}$. IR spectrum, $v, \mathrm{~cm}^{-1}: 1592(-\mathrm{HC}=\mathrm{N}), 2215(-\mathrm{C} \equiv \mathrm{N}) .{ }^{1} \mathrm{H}$ NMR $\left(300 \mathrm{MHz}, \mathrm{DMSO}^{\left.-\mathrm{d}_{6}\right)} \delta\right.$ in ppm: 6.84-8.07 $(\mathrm{m}, 16 \mathrm{H}, \mathrm{Ar}-\mathrm{H})$, $1.98\left(\mathrm{~s}, 3 \mathrm{H},-\mathrm{CH}_{3}\right), 9.11(\mathrm{~s}, 1 \mathrm{H},-\mathrm{CH}=\mathrm{N}), 3.05(\mathrm{~s}, 6 \mathrm{H},-\mathrm{N}-$ $\left.\mathrm{CH}_{3}\right) \cdot{ }^{13} \mathrm{C}$ NMR $\left(100 \mathrm{MHz}\right.$, DMSO-d $\left.\mathrm{d}_{6}\right) \delta$ in ppm: 161.42 , $160.56,154.62,151.29,149.51,129.11,128.25,125.42,123.96$, 115.88, 40.82, 27.08; MS $(\mathrm{m} / z)$ : $509(\mathrm{M}+)$. Anal. calc. for $\mathrm{C}_{29} \mathrm{H}_{25} \mathrm{ClN}_{6} \mathrm{O}$. (\%): C, 68.43; H, 4.95; Cl, 6.96; N, 16.51 . Found: C, 68.36; H, 4.86; Cl, 6.81; N, 16.38 .

2.1.7. (E)-4-(((5-Chloro-6-((2-(4-(thiazol-2-yloxy)phenyl)$1 \mathrm{H}$-pyrrol-1-yl)methyl)pyridin-2-yl)imino)methyl)-N,N-dimethylaniline (7). Yellow solid. Yield $60 \%, \mathrm{mp} 193^{\circ} \mathrm{C}$. IR spectrum, $v, \mathrm{~cm}^{-1}: 1550(-\mathrm{HC}=\mathrm{N}), 2214(-\mathrm{C} \equiv \mathrm{N}) .{ }^{1} \mathrm{H}$ NMR $(300 \mathrm{MHz}$, DMSO- $\left.\mathrm{d}_{6}\right) \delta$ in ppm: $6.68-8.09(\mathrm{~m}, 15 \mathrm{H}, \mathrm{Ar}-\mathrm{H}), 8.93(\mathrm{~s}, 1 \mathrm{H}$, $-\mathrm{CH}=\mathrm{N}), 3.08\left(\mathrm{~s}, 6 \mathrm{H},-\mathrm{N}-\mathrm{CH}_{3}\right) .{ }^{13} \mathrm{C}$ NMR $(100 \mathrm{MHz}$, DMSO$\left.\mathrm{d}_{6}\right) \delta$ in ppm: $181.09,172.16,164.56,155.21,154.63,136.32$, 131.97, 127.89, 112.87, 40.82; MS (m/z): $514\left(\mathrm{M}^{+}\right)$. Anal. calc. for $\mathrm{C}_{28} \mathrm{H}_{24} \mathrm{ClN}_{5} \mathrm{O}_{5}(\%)$ : C, 65.42; $\mathrm{H}, 4.71 ; \mathrm{Cl}, 6.90 ; \mathrm{N}, 13.62 ; \mathrm{S}$, 6.24. Found: C, 65.36; H, 4.71; Cl, 6.78; N, 13.53; S, 6.14 .

2.1.8. (E)-4-((5-Chloro-6-((2-(4-(pyridazin-3-yloxy)phenyl)1H-pyrrol-1-yl)methyl)pyridin-2-yl)imino)methyl)-N,N-dimethylaniline (8). Yellow solid. Yield $67 \%, \mathrm{mp} 195^{\circ} \mathrm{C}$. IR spectrum, $v$, $\mathrm{cm}^{-1}: 1550(-\mathrm{HC}=\mathrm{N}) 2212(-\mathrm{C} \equiv \mathrm{N}) .{ }^{1} \mathrm{H}$ NMR $(300 \mathrm{MHz}$, DMSO- $\left.\mathrm{d}_{6}\right) \delta$ in ppm: 6.38-8.35 (m, 16H, Ar-H), $9.18(\mathrm{~s}, 1 \mathrm{H}$, $-\mathrm{CH}=\mathrm{N}), 3.05\left(\mathrm{~s}, 6 \mathrm{H},-\mathrm{N}-\mathrm{CH}_{3}\right), 2.79(\mathrm{~s}, 1 \mathrm{H},-\mathrm{CH}) .{ }^{13} \mathrm{C}$ NMR $\left(100 \mathrm{MHz}, \mathrm{DMSO}-\mathrm{d}_{6}\right) \delta$ in ppm: $162.151,150.231,146.954$, 144.151, 132.847, 127.624, 117.751, 40.62; MS $(\mathrm{m} / z): 509.0$ $(\mathrm{M}+1)$. Anal. calc. for $\mathrm{C}_{29} \mathrm{H}_{25} \mathrm{ClN}_{6} \mathrm{O}(\%)$ : $\mathrm{C}, 68.43 ; \mathrm{H}, 4.95$; $\mathrm{Cl}, 6.96 ; \mathrm{N}, 16.51$. Found: C, 68.13; H, 4.82; Cl, 6.81; N, 16.37 .

2.2. DNA Binding Study and Antioxidant Assay. To study the DNA interaction with most potent compound, various spectroscopic techniques were employed and DPPH free radical and hydrogen peroxide were used to evaluate the antioxidant assay of the compounds according to our reported research work [32-35]. Detail methodology is given in supplementary file (Table S1).

\section{Results and Discussion}

3.1. Structural Determination. Synthetic route for the preparation of the Schiff bases 1-8 is given in Scheme 1. All the derivatives were synthesized in good yields with characteristic colour. Compounds were soluble in chloroform and DMSO but insoluble in water. Melting points were in the range of $193-273^{\circ} \mathrm{C}$. Thin-layer chromatography (TLC) was used to monitor the progress of the reaction in methanol: dichloromethane $(1: 4)$.

The stretching frequency due to $-\mathrm{NH}_{2}$ and $-\mathrm{C}=\mathrm{O}$ of all the substituted amines and carbonyls disappears in the target compounds (1-8) which confirms the structure of Schiff bases. In the IR spectra of all compounds, a sharp peak appeared in the range of $1575-1605 \mathrm{~cm}^{-1}$ which is the most characteristic feature of Schiff base azomethine $(-\mathrm{C}=\mathrm{N})$ group, and a broad absorption band in the range of $2200-2218 \mathrm{~cm}^{-1}$ for all compounds (1-8) was attributed to the $-\mathrm{C} \equiv \mathrm{N}$ stretching. The bands appearing at $957-802 \mathrm{~cm}^{-1}$ may be assigned to ring breathing mode, $\mathrm{C}-\mathrm{H}$ deformation, and $\mathrm{C}-\mathrm{C}$ deformations.

${ }^{1} \mathrm{H}$ NMR spectra (DMSO- $\mathrm{d}_{6}$ ) at room temperature exhibited well-resolved signals. The signal due to $-\mathrm{CH}=\mathrm{N}$ appears in the range of $8.5-9.5 \mathrm{ppm}$ for the compounds corresponding to azomethine group which confirms the formation of Schiff bases. Moreover, a peak appears in $3.01-3.13 \mathrm{ppm}$ range attributed to the $-\mathrm{CH}_{3}(6 \mathrm{H})$ aliphatic for the compounds (1-8). A signal at $\delta 1.80-2.20 \mathrm{ppm}$ may be assigned to the protons of the $\left(\mathrm{C}-\mathrm{CH}_{2}-\mathrm{C}, 8 \mathrm{H}\right)$ for the compounds $2,3,\left(\mathrm{C}-\mathrm{CH}_{2}-\mathrm{C}, 10 \mathrm{H}\right)$ for the compounds 4,5 , and $\left(\mathrm{C}-\mathrm{CH}_{2}-\mathrm{C}, 2 \mathrm{H}\right)$ for the compounds 6-8. Aromatic protons appear at $6.38-8.52 \mathrm{ppm}$ range.

The electronic impact mass of Schiff bases of $p$-dimethylaminobenzaldehyde derivatives (1-8) showed molecular ion peaks at $m / z=314.4,344.4,420.0,358.4,434.5,509.0$, 514.0 , and 509.0 atomic mass units corresponding to species $\left[\mathrm{C}_{18} \mathrm{H}_{18} \mathrm{~N}_{6}\right]^{+}, \quad\left[\mathrm{C}_{20} \mathrm{H}_{20} \mathrm{~N}_{6}\right]^{+}, \quad\left[\mathrm{C}_{26} \mathrm{H}_{24} \mathrm{~N}_{6}\right]^{+}, \quad\left[\mathrm{C}_{21} \mathrm{H}_{22} \mathrm{~N}_{6}\right]^{+}$, $\left[\mathrm{C}_{27} \mathrm{H}_{26} \mathrm{~N}_{6}\right]+{ }^{+},\left[\mathrm{C}_{29} \mathrm{H}_{25} \mathrm{ClN}_{6} \mathrm{O}\right]^{+},\left[\mathrm{C}_{28} \mathrm{H}_{24} \mathrm{ClN}_{5} \mathrm{O}_{5}\right]^{+}$, and $\left[\mathrm{C}_{29} \mathrm{H}_{25} \mathrm{ClN}_{6} \mathrm{O}\right]^{+}$, which confirmed the proposed formula.

The ${ }^{1} \mathrm{H}$ NMR, ${ }^{13} \mathrm{C}$ NMR, and mass spectra of compounds (1-8) are represented in supporting information (Figures S1-S24).

\subsection{DNA Binding Studies}

3.2.1. Absorption Measurements. Electronic absorption spectroscopy is an essential tool which is applied for evaluating the binding way of DNA with the examined compounds and the extent of binding as well [36]. The absorption titration experiments were carried out using constant concentrations of the studied compounds $(50 \mu \mathrm{M})$ while progressively increasing the concentration of DNA at $25^{\circ} \mathrm{C}(5-45 \mu \mathrm{M})$. The absorbance of DNA is cancelled by adding equivalent amounts of DNA to both of the tested compounds and reference solutions. The absorption spectra of compounds 1-8 in the absence and existence of raising concentrations of DNA are presented in Figure 1. The intrinsic binding constant $(\mathrm{Kb})$ of compound with DNA is computed by precise noticing of the intensity of the CT bands. In the case of intercalation mode of binding between the compound and DNA, the obvious spectral feature of the band under study is hypochromism with small shift in wavelength; occasionally, no shift is observed. This is because the intercalative type of interaction comprises a significant interaction between the aromatic chromophore of the complex compounds and DNA base pairs [37]. The extent of absorbance lowering, hypochromism, is ordinarily convenient with the extent of intercalation. The other obvious spectral feature is hyperchromism. The hyperchromism is consistent with the fracturing of the secondary DNA structure [38]. The binding ability and extent of binding between compounds 1-8 and DNA are discussed based on absorbance as a function of added DNA 

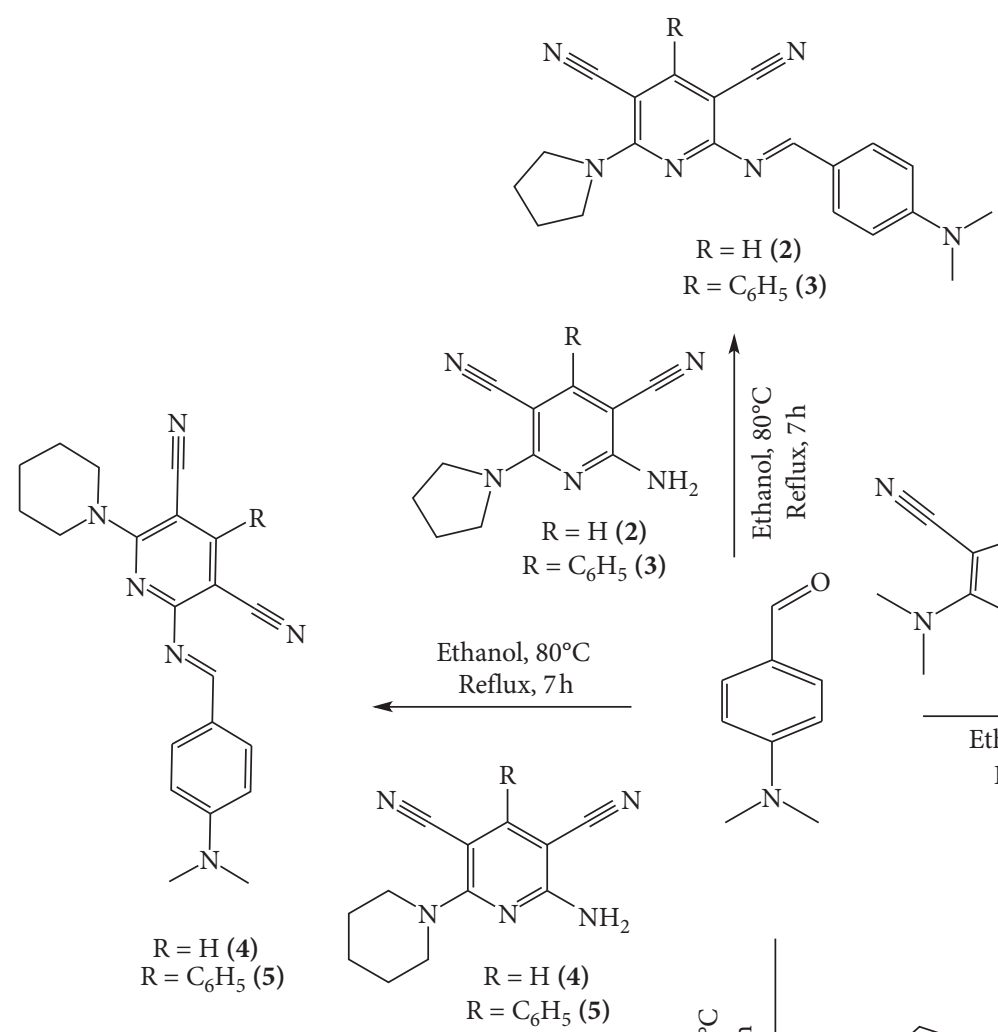<smiles>CN(C)c1ccc(C=O)cc1</smiles><smiles>CN(C)c1nc(N)c(C#N)cc1C#N</smiles>

Ethanol, $80^{\circ} \mathrm{C}$ Reflux, $7 \mathrm{~h}$<smiles>CN(C)c1ccc(/C=N/c2nc(C#N)cc(C#N)c2N(C)C)cc1</smiles>

(1)

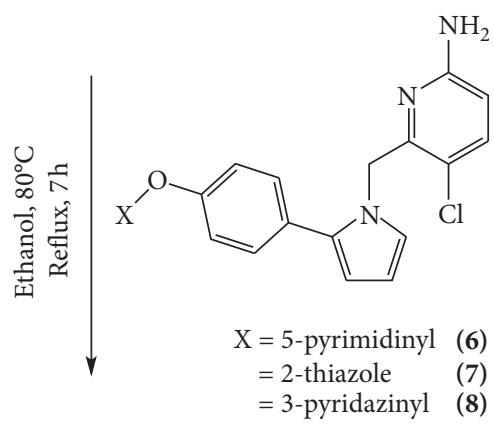<smiles>[X]Oc1ccc(-c2cccn2Cc2nc(/N=C/c3ccc(N(C)C)cc3)ccc2Cl)cc1</smiles>

$$
\begin{aligned}
\mathrm{X} & =5 \text {-pyrimidinyl } \\
& =2 \text {-thiazole } \\
& =3 \text {-pyridazinyl }
\end{aligned}
$$

Scheme 1: Synthesis of Schiff bases of $p$-dimethylaminobenzaldehyde derivatives (1-8).

concentration. The data were obtained by raising the concentration of DNA in the range $5-45 \mu \mathrm{M}$, and the absorption bands of the compounds 1 and 4 at 396 and $393 \mathrm{~nm}$ exhibited hypochromism of 4.4 and $18.2 \%$, respectively. These data recommended strong association of the test compounds with SS-DNA, and it is also more likely that the interaction mode is intercalation. On the contrary, compounds $2,3,5,6,7$, and 8 exhibited hyperchromism of 20.2 , $24.6,28.7,30.3,24.8$, and $18.9 \%$, respectively, of the CT bands appearing at 469, 402, 471, 394, 403, and 407, respectively. This spectral change can be vindicated by groove binding mode [39]. To illustrate the extent of binding of compounds to DNA quantitatively, $\mathrm{Kb}$ was calculated using the following equation:

$$
\frac{[\mathrm{DNA}]}{\varepsilon \mathrm{a}-\varepsilon \mathrm{f}}=\frac{[\mathrm{DNA}]}{\varepsilon \mathrm{b}-\varepsilon \mathrm{f}}+\frac{1}{[\mathrm{~Kb}(\varepsilon \mathrm{b}-\varepsilon \mathrm{f})]},
$$

where [DNA] is the concentration of DNA solution in the base pairs. The absorption coefficient $\varepsilon$ a equals $\mathrm{A}_{\mathrm{obs}} /$ [compound], and $\varepsilon f$ and $\varepsilon b$ refer to the extinction coefficient of the unbounded compound and the compound in a fully bound state to DNA, respectively. The plot of [DNA] $/\left(\varepsilon_{\mathrm{a}}-\varepsilon_{\mathrm{f}}\right)$ 


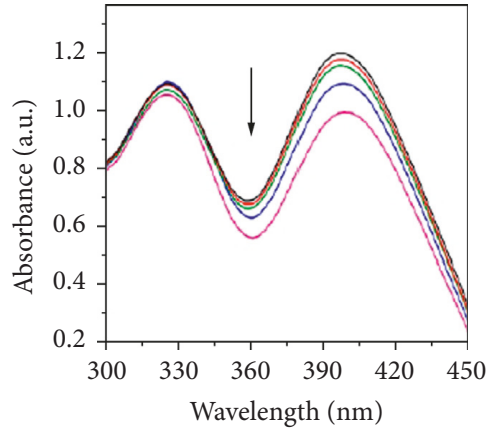

(a)

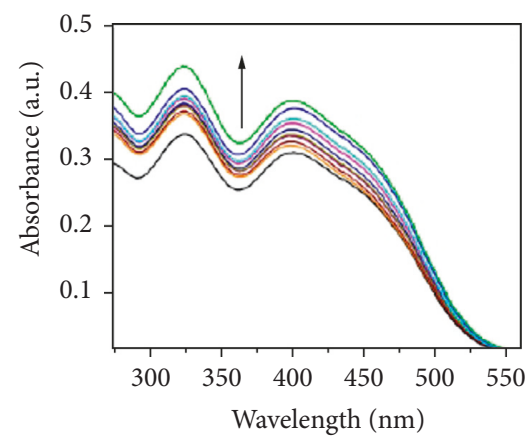

(d)

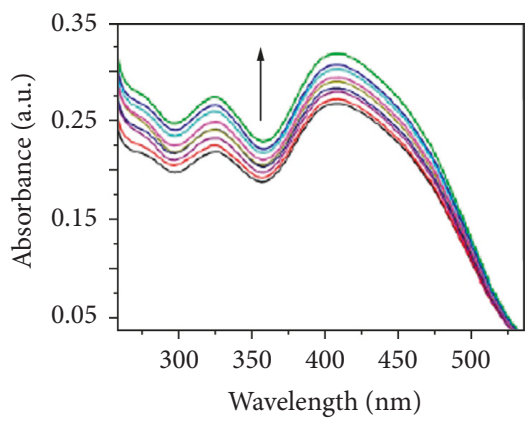

(g)

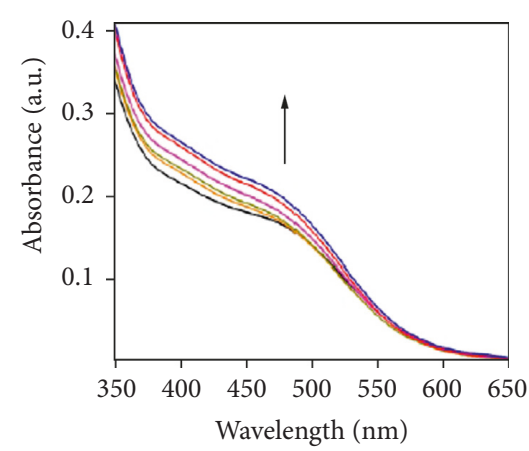

(b)

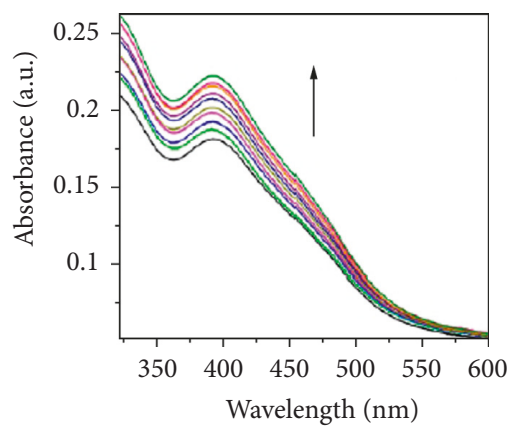

(e)

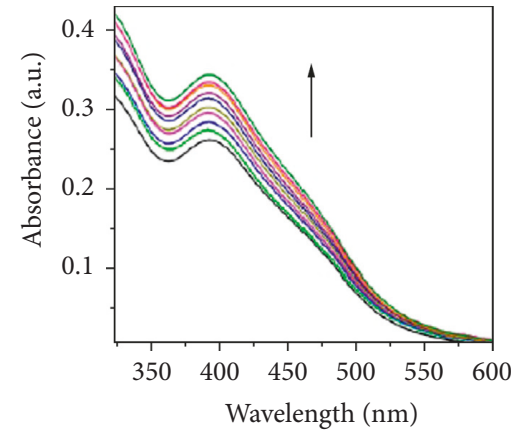

(c)

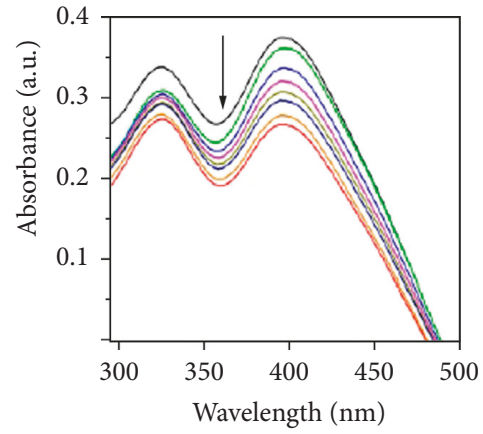

(f)

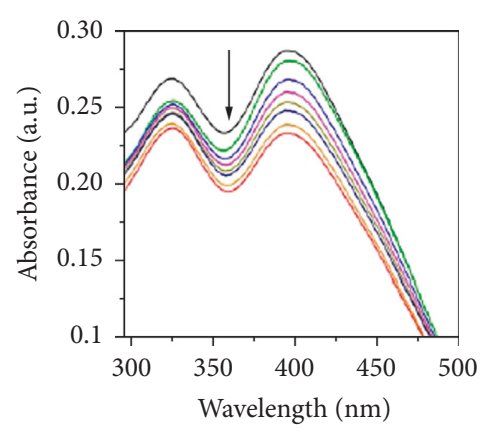

(h)

Figure 1: Absorption spectra of heterocyclic Schiff base derivatives 1-8 (a-h) upon the titration of salmon sperm DNA (SS-DNA). Arrow indicates the absorption change upon increasing the DNA concentration.

versus [DNA] is straight line with slope $=1 /\left(\varepsilon_{\mathrm{b}}-\varepsilon_{\mathrm{f}}\right)$ and intercept $=1 / K_{\mathrm{b}}\left(\varepsilon_{\mathrm{b}}-\varepsilon_{\mathrm{f}}\right) ; K_{\mathrm{b}}$ is calculated from the ratio of slope to intercept. Analyses of the calculated $K_{\mathrm{b}}$ values of the studied compounds illustrate that the examined compounds have moderate binding ability when these values are compared with ethidium bromide which is the most familiar intercalators [40]. The obtained values of the binding constant $\left(K_{\mathrm{b}}\right)$ were found to be $1.98 \times 10^{4}, 1.77 \times 10^{4}$, $1.29 \times 10^{4}, 1.78 \times 10^{4}, 1.38 \times 10^{3}, 2.54 \times 10^{4}, 3.4 \times 10^{3}$, and $7.7 \times 10^{3}$ for compounds $\mathbf{1}-\mathbf{8}$, respectively.

3.2.2. Viscosity Measurements. The optical tools provide substantial, but not sufficient, evidence to support the intercalative type of interaction between compounds and DNA. A hydrodynamic tool, like viscosity, that introduces large accuracy to any change in DNA length is probably the influential tool in order to evaluate the binding mode between tested compounds and DNA. The viscosity of DNA solutions is recorded using different dilutions of the compounds reported in this paper (compounds 1-8) using constant concentration of DNA solution. Figure 2 shows the influence of increasing concentrations of the compounds on DNA viscosity. Viscosity measurement of DNA is regarded a classic way to assess the DNA type of interaction in solution. Under the normal conditions, ethidium bromide (EB), as a known example of intercalators, usually results in a considerable enhancement in DNA viscosity which results from the increase in the distance detaching the intercalation site base pairs that result in a final augmentation in the DNA length [38-40], as obvious in Figure 2. For compounds 1 and 5 , the obtained results suggest that the compounds under study can intercalate among the adjacent DNA base pairs, resulting in elongation in the double spiral and subsequently 


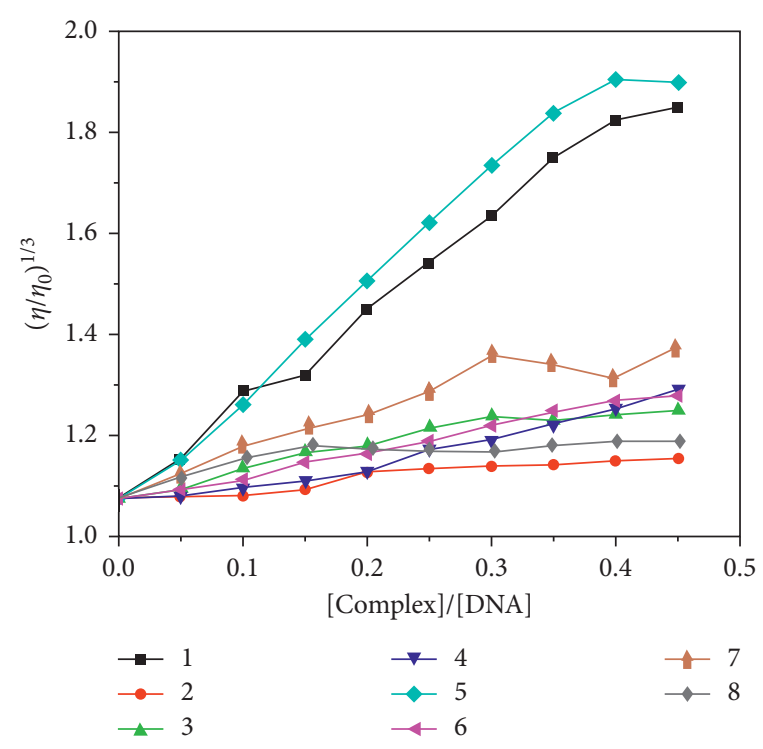

FIGURE 2: Effects of increasing amounts of heterocyclic Schiff base derivatives (1-8) on the relative viscosity of DNA at $\mathrm{pH} 7.4$ and $25^{\circ} \mathrm{C}$; $[\mathrm{DNA}]=5.5 \times 10^{-5} \mathrm{M}$ and $[$ compound $]=0.5-2.5 \times 10^{-4} \mathrm{M}$.

raising the DNA viscosity. This raise in the propensity of the viscosity curves by adding increasing amounts of the tested compounds strongly suggests intercalation binding mode. For compounds $\mathbf{2 - 4}$ and 6-8, the relative viscosity of the DNA solution was almost unchanged or increasing slowly over the entire tested range when compared with compounds 1 and 5 which suggests that the interactions between these compounds and DNA may be electrostatic forces groove binding type.

3.2.3. Fluorescence Spectroscopy. The mechanism of interaction between compound and Ct-DNA was determined by fluorescence quenching studies. The fluorescence spectra of heterocyclic Schiff base derivatives $\mathbf{1 - 8}$ are presented in Figure 3 . The fluorescence intensity decreases significantly upon addition of DNA due to interaction of compound with DNA. The binding constant and binding affinities from fluorescence spectral data can be calculated using the following modified Scatchard relation [41]:

$$
\log \left[\frac{I_{o}-I}{I}\right]=\log \mathrm{K}_{\mathrm{b}}+n_{\mathrm{b}} \log [\mathrm{DNA}]
$$

where $K_{\mathrm{b}}$ is the binding constant and $n_{\mathrm{b}}$ refers to number of binding sites. $I$ and $I_{\mathrm{o}}$ are the fluorescence intensities in the presence and absence of DNA, respectively.

The binding constant $K_{\mathrm{b}}$ was calculated to be $1.21 \times 10^{4}$, $1.22 \times 10^{4}, 1.24 \times 10^{4}, 1.21 \times 10^{4}, 1.19 \times 10^{4}, 1.20 \times 10^{4}$, $1.23 \times 10^{4}$, and $1.18 \times 10^{4} \mathrm{M}^{-1}$ for $\mathbf{1 - 8}$, respectively. Results suggested that quenching effect of solvent molecule is prevented by hydrophobic environment of compounds inside the DNA helix. The quenching of emission of compounds is due to photoelectron transfer from the nitrogenous base (guanine) to excited states of the compounds $[42,43]$. Hence, it is conventional that compounds bind with DNA by way of electrostatic mode of binding or groove binding mode and results are well validated with UV-visible and hydrodynamic studies.

3.2.4. Cyclic Voltammetry. Electrochemical methods provide a useful complement in support of UV-visible and viscosity measurements methods. The electrochemical behavior of compounds was studied in Tris-buffer solution (5.0 mM Tris- $\mathrm{HCl}, 50 \mathrm{mM} \mathrm{NaCl}, \mathrm{pH} 7.2$ ) and an aqueous $\mathrm{Ag} / \mathrm{AgCl}$ reference electrode with $3.0 \mathrm{M} \mathrm{NaCl}$ in saturated $\mathrm{AgCl}$ as the filling solution was used (Figure 4). Cyclic voltammogram showed irreversible one-step oxidation process for the test compounds. The interaction of DNA with compounds can be assessed on the basis of shifting in peak potential and decrease in peak heights in the cyclic voltammogram $[44,45]$. The positive shift in peak current is due to the intercalation of the compound with Ct-DNA. However, the electrostatic binding leads to the negative shift in peak current. From the cyclic voltammogram, it can be inferred that after the addition of DNA to compound, peak current was dropped by $28.27 \%, 23.55 \%, 26.48 \%, 34.92 \%$, $27.76 \%, 32.33 \%, 35.45 \%$, and $53.71 \%$ for compounds $\mathbf{1 - 8}$, respectively (Figure 4 ). The decrease in voltammetric current leads to formation of ligand-DNA complex which may be due to the acclimation of ligand between the adjoining base pairs of Ct-DNA. These results could be attributed to the diffusion of free ligand and DNA molecule and changes in peak currents after the addition of Ct-DNA due to the DNAbinding affinity of the compounds.

3.3. Circular Dichroism Study. Circular dichroism (CD) spectroscopy has been performed for monitoring the structural variations occurred upon interaction of compounds and DNA. In the CD spectrum of Ct-DNA, two characteristic bands appear, one is a negative band at $249 \mathrm{~nm}$ and other is positive band at $277 \mathrm{~nm}$ corresponding to the helicity of B-DNA and due to $\pi-\pi$ base stacking, respectively. Secondary structure of DNA can be perturbed because intercalation and intensity of positive and negative bands change whereas groove binding makes little or no perturbation on the base stacking and helicity bands. The change in CD signals on addition of the compound to DNA leads to disturbance in nucleotide base sequence of binding and base stacking of DNA attributed to conformational changes in DNA molecules shown in Figure 5 [46]. Thus, the observed result supported to electrostatic or groove mode of binding.

3.4. Molecular Docking Study. An attractive tool to investigate compound and DNA interactions for the planning and development of new drugs is molecular docking. Dodecamer sequence (B-DNA) is very abundant in natural DNA. The binding modes of compounds or a set of related compounds can bind in different modes to a specific binding site of DNA or a protein. This is especially evident from $\mathrm{X}$-ray crystallographic structures of ligand-protein complexes. The availability of multiple binding modes of a ligand in a binding site may present an advantage in drug design 

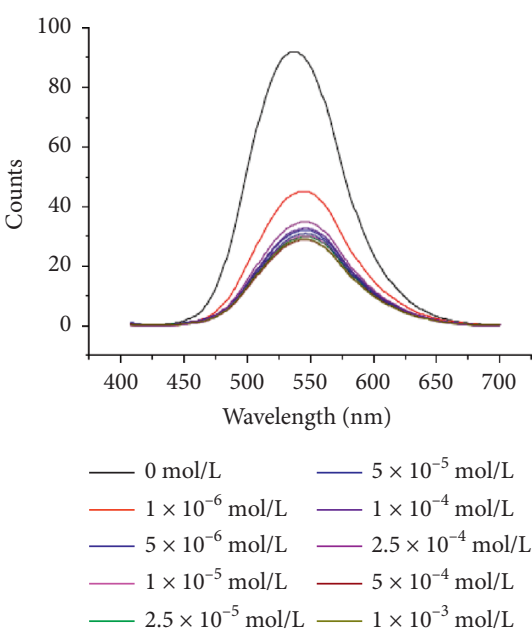

(a)
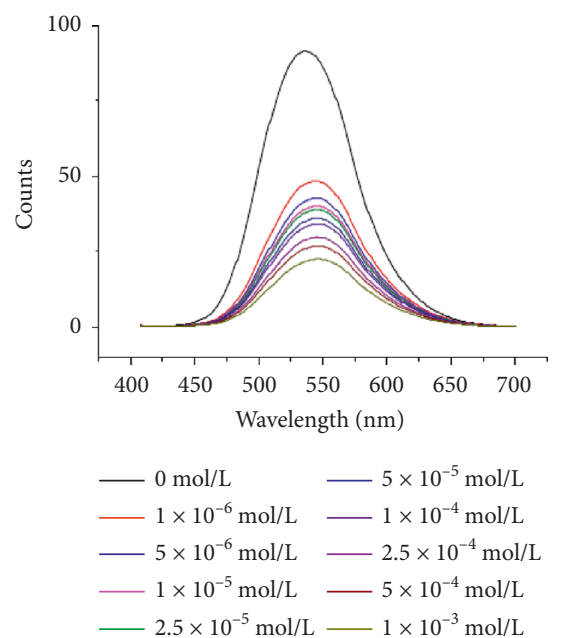

(d)

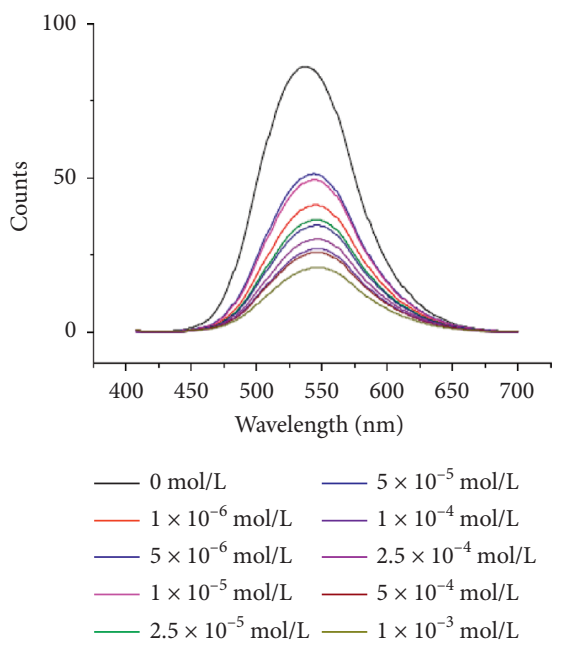

(g)
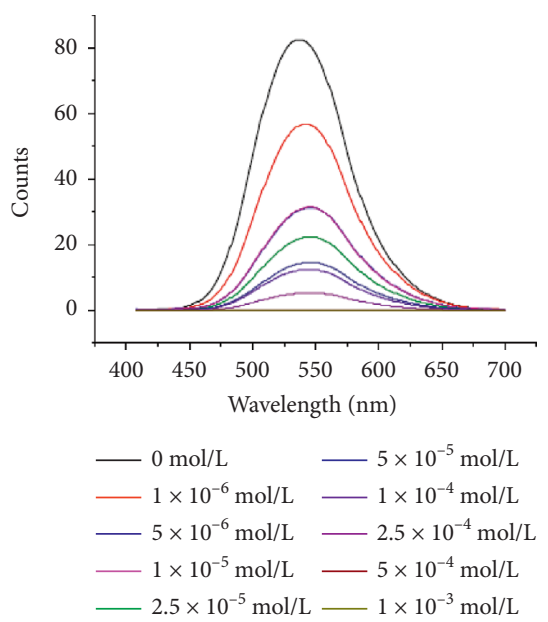

(b)
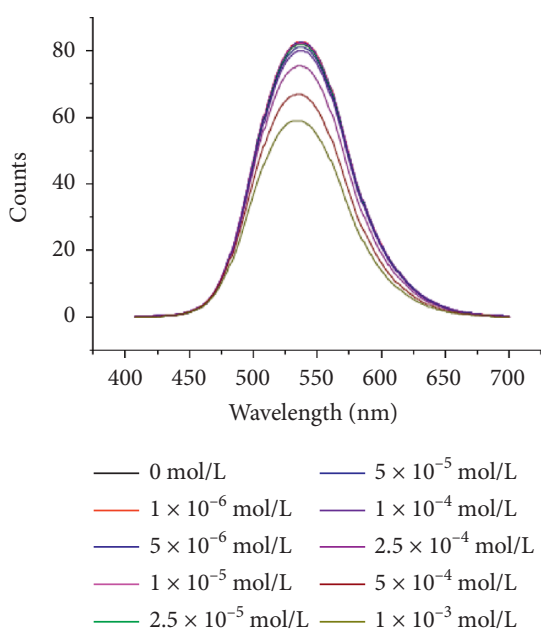

(e)
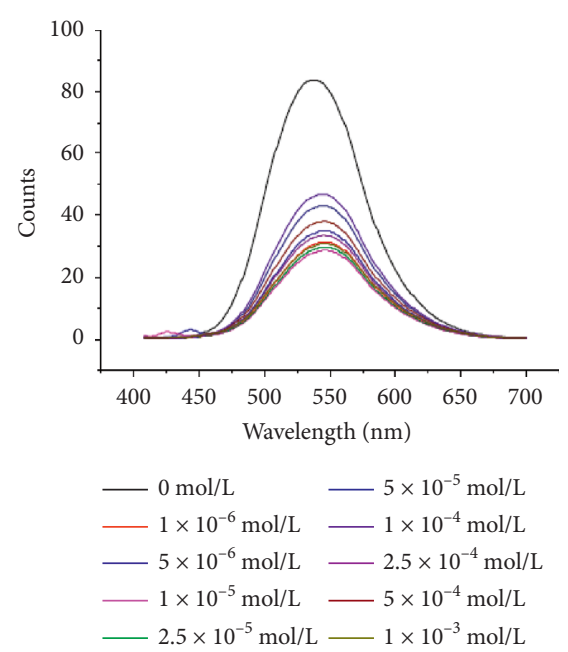

(h)

FIGURE 3: Fluorescence emission spectra of heterocyclic Schiff base derivatives 1-8 $(\mathrm{a}-\mathrm{h})\left(2.7 \times 10^{-4} \mathrm{M}\right)$ in the presence of increasing [DNA] $\left(5.6-6.2 \times 10^{-5} \mathrm{M}\right)$.

when simultaneously optimizing several criteria [47]. Docking of the synthesized heterocyclic Schiff base derivative (1-8) was carried out with DNA duplex of the

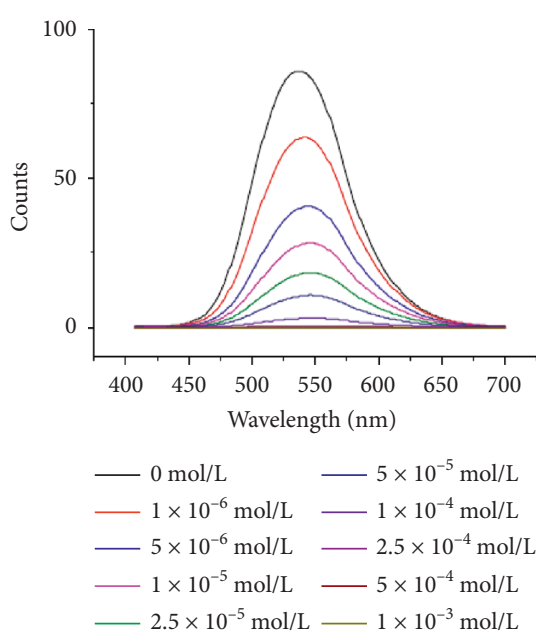

(c)
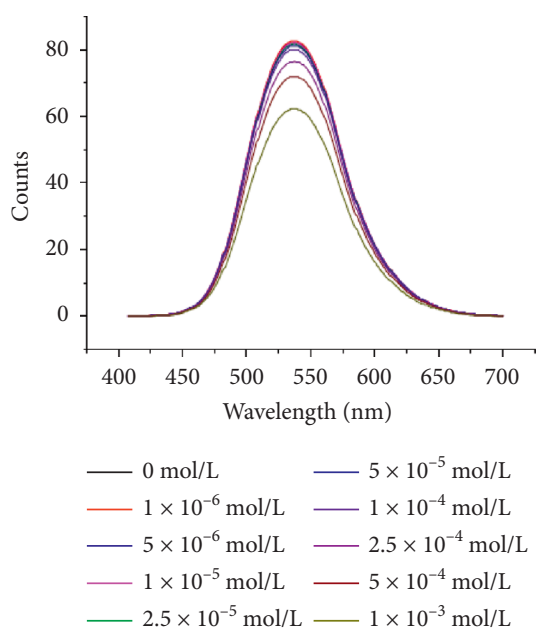

(f) 


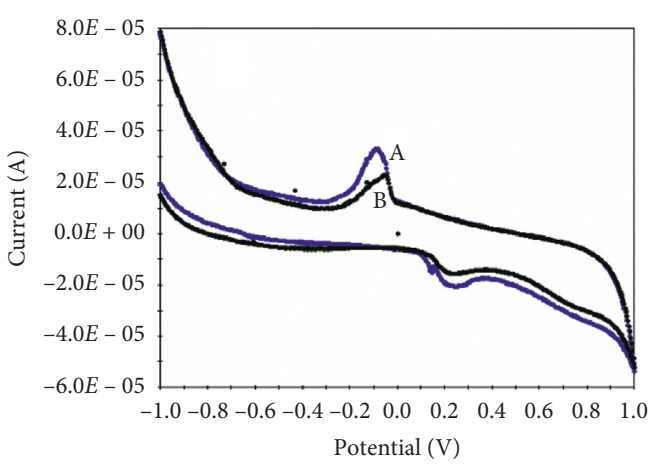

(a)

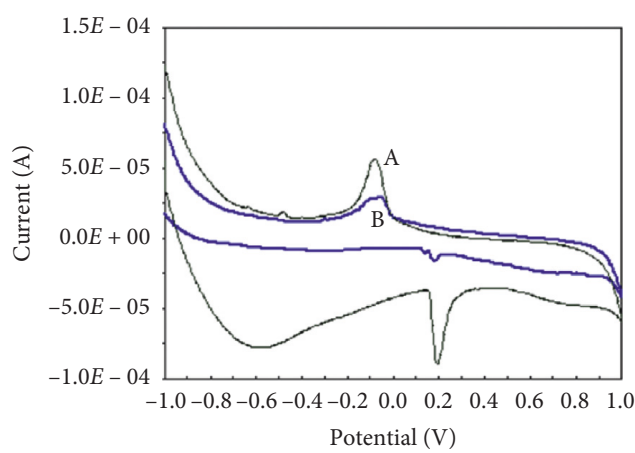

(c)

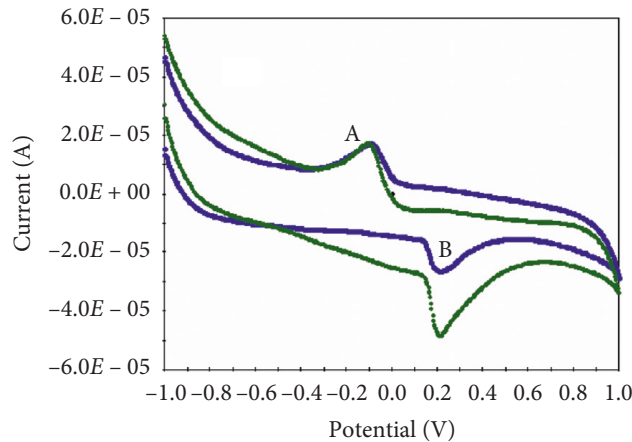

(e)

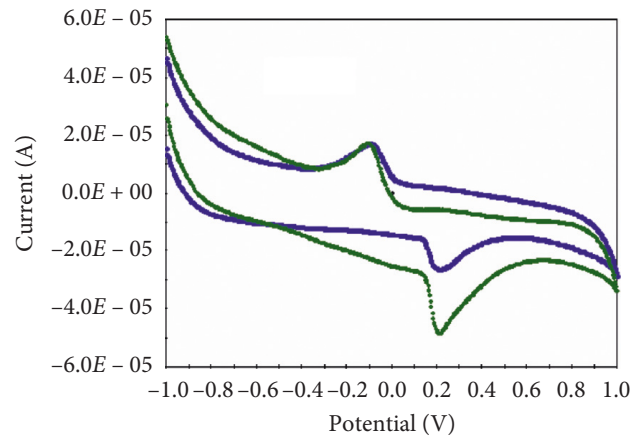

(g)

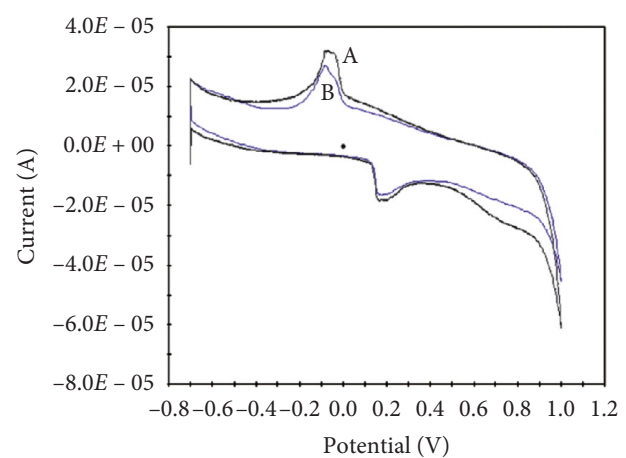

(b)

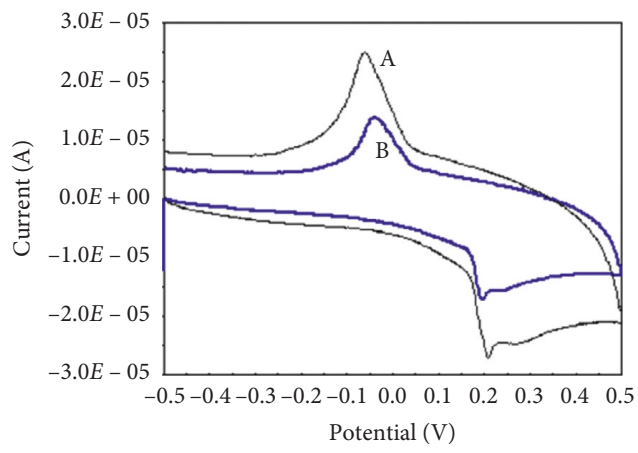

(d)

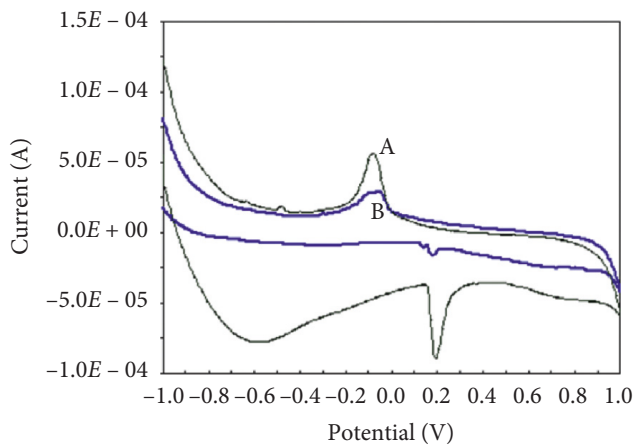

(f)

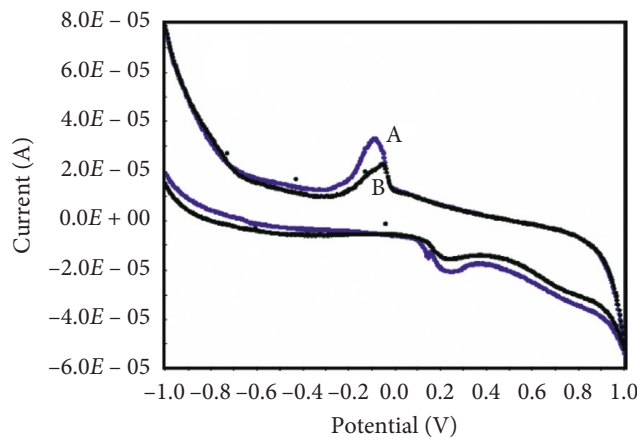

(h)

Figure 4: Cyclic voltammogram of heterocyclic Schiff base derivatives 1-8 $(\mathrm{a}-\mathrm{h})\left(30 \mu \mathrm{mol} \mathrm{L}{ }^{-1}\right)$ in the absence (A) and presence (B) of $30 \mu \mathrm{mol} \mathrm{L}-1$ of DNA at $100 \mathrm{mV} / \mathrm{s}$ scan rate in $5 \mathrm{mM}$ Tris with $\mathrm{pH} 7.2$.

Compounds 1-8 interact with DNA helix at regions of DA5; DC3, DG4; DC3; DC3; DA16, DA17; DA18; DA4, DA5; and DG4, DT20 with binding energies of $-7.79,-8.47,-7.79$, $-8.37,-8.46,-6.79,-7.32$, and -7.17 , respectively.
Compounds 1-5 showed heist binding activity with 1BNA followed by other compounds, as shown in Table 1. Docked compounds were analysed in terms of hydrogen bonding, energy, noncovalent, and hydrophobic interaction between 


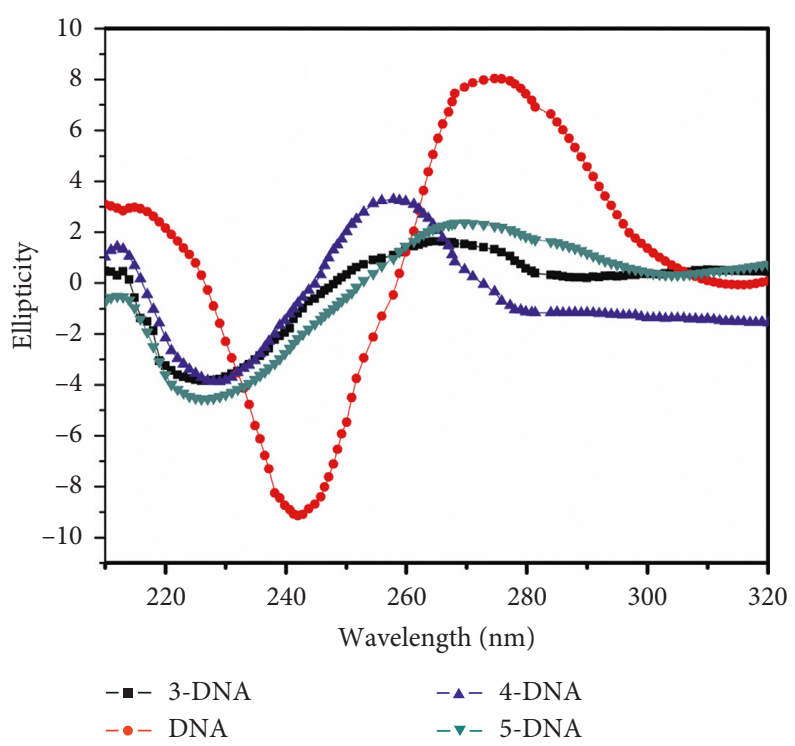

Figure 5: CD spectrum of Ct-DNA $\left(5.5 \times 10^{-5} \mathrm{M}\right)$ in the absence and presence of heterocyclic Schiff base derivatives 3,4 , and 5 in $5 \mathrm{mM}$ Tris buffer.

TABLe 1: Molecular docking study of heterocyclic Schiff base derivatives (1-8).

\begin{tabular}{|c|c|c|c|c|c|c|c|c|c|}
\hline Compounds & $\begin{array}{l}\text { Cluster } \\
\text { run }\end{array}$ & $\begin{array}{c}\Delta \mathrm{G} \\
(\mathrm{kcal} / \\
\mathrm{mol})\end{array}$ & $\begin{array}{c}E_{\text {inter-mol }} \\
(\mathrm{kcal} / \mathrm{mol})\end{array}$ & $\begin{array}{c}E_{\text {elec }} \\
(\mathrm{kcal} / \\
\mathrm{mol})\end{array}$ & $\begin{array}{c}E_{\text {torsional }} \\
(\mathrm{kcal} / \mathrm{mol})\end{array}$ & $\begin{array}{c}K i_{\text {inhibition }} \\
\text { constant }(\mathrm{M})\end{array}$ & $\begin{array}{c}\text { Cluster } \\
\text { RMSD (A) }\end{array}$ & $\begin{array}{l}\text { Reference } \\
\text { RMSD (A) }\end{array}$ & $\begin{array}{l}\text { NB involved in } \\
\text { bonding }\end{array}$ \\
\hline 1 & 40 & -7.77 & -7.77 & -7.83 & +1.67 & $0.00 e+00$ & 0.00 & 32.344 & DC3, DG4 \\
\hline 2 & 47 & -8.47 & -8.47 & -8.48 & +1.12 & $0.00 e+00$ & 0.00 & 30.367 & DC3 \\
\hline 3 & 9 & -7.79 & -8.31 & +0.03 & +0.84 & $2.05 \mu \mathrm{M}$ & 0.00 & 26.531 & DG4, DA5 \\
\hline 4 & 48 & -8.37 & -8.37 & -8.39 & +1.39 & $0.00 e+00$ & 0.00 & 27.519 & DC3 \\
\hline 5 & 4 & -8.46 & -8.46 & -8.48 & +1.12 & $0.00 \mathrm{e}+00$ & 0.00 & 26.745 & DA18 \\
\hline 6 & 47 & -6.79 & -7.31 & -0.13 & +0.84 & $10.90 \mu \mathrm{M}$ & 0.00 & 26.481 & DA5 \\
\hline 7 & 52 & -7.32 & -8.62 & -0.13 & +1.39 & $4.51 \mu \mathrm{M}$ & 0.00 & 26.810 & DA16, DA17 \\
\hline 8 & 20 & -7.17 & -7.74 & -0.00 & +0.84 & $5.76 \mu \mathrm{M}$ & 0.00 & 26.783 & DG4, DT20 \\
\hline
\end{tabular}

compounds and DNA (Figure 6) [48, 49]. The docked results clearly explained that there is strong interaction between the compounds and 1BNA.

3.5. In Vitro Antibacterial Susceptibility Assay. The in vitro evaluation was carried out to provide antimicrobial capability of heterocyclic Schiff base derivatives (1-8), and the experimental results are shown in Table 2. Compounds 1-8 are significantly active against Staphylococcus aureus ( $S$. aureus), Escherichia coli (E. coli), and Aspergillus niger (A. niger) also at a concentration level of $200-25 \mu \mathrm{g} / \mathrm{mL}$. Ofloxacin and ketoconazole were used as standards for comparison of antibacterial and antifungal activity under the similar conditions. DMSO was used as a solvent control for both antibacterial and antifungal activities, and the results are presented in minimal inhibition concentration (MIC) values $(\mu \mathrm{g} / \mathrm{mL})$. Compound 1 exhibited low antimicrobial activity (MIC $200 \mu \mathrm{g} / \mathrm{mL}$ ) compared to the reference substances ofloxacin and ketoconazole. On the contrary, a minor increase in antimicrobial activity was achieved with the three compounds 2, 3, and 6 exhibiting an MIC of $150-200 \mu \mathrm{g} / \mathrm{mL}, \quad 150-200 \mu \mathrm{g} / \mathrm{mL}$, and $150-200 \mu \mathrm{g} / \mathrm{mL}$ against S. aureus, E. coli, and A. niger. Compounds 4, 5, and 8 displayed promising antibacterial activities (MIC 50-75 $\mu \mathrm{g}$ / $\mathrm{mL}$ ) against all tested culture strains used in the present study. In contrast, the antimicrobial results observed for compound 7 (MIC $125 \mu \mathrm{g} / \mathrm{mL}$ ) was clearly lower. The high lipophilicity of the synthesized compounds $(\log P$ 2.674.42 ) promoted us to investigate the possibility of a correlation between the type of chemical substitution and the antimicrobial activity of the title compounds; therefore, the linear regression of the partition coefficient with the biological activity expressed as MIC $(\mu \mathrm{g} / \mathrm{mL})$ for the synthesized compounds was studied [50].

\subsection{Antioxidant Assay}

3.6.1. DPPH Radical Scavenging Activity. 2,2-Diphenyl-1-picryl-hydrazyl is a free radical which was used for the determination of antioxidant activity. It can accept electron or hydrogen from the compound and get reduced. After the incubation of one hour, colour was changed from violet to blue and absorbance was decreased. The absorbance at $517 \mathrm{~nm}$ was measured and $\mathrm{IC}_{50}$ values 


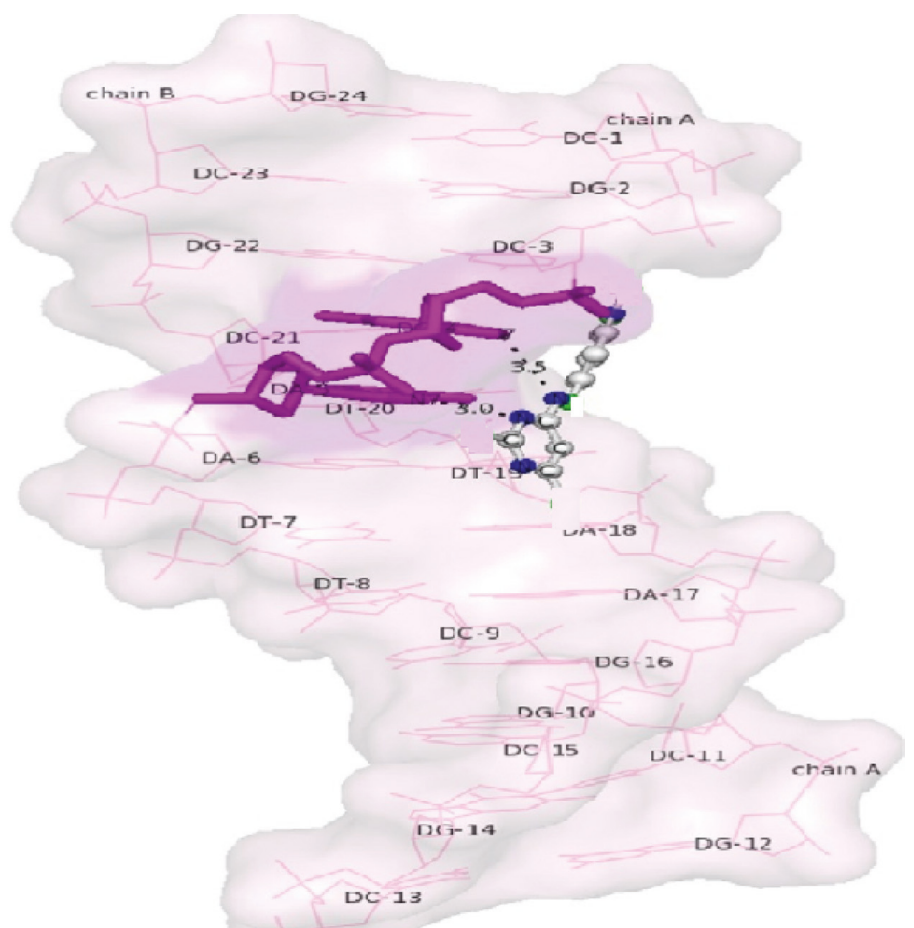

(a)

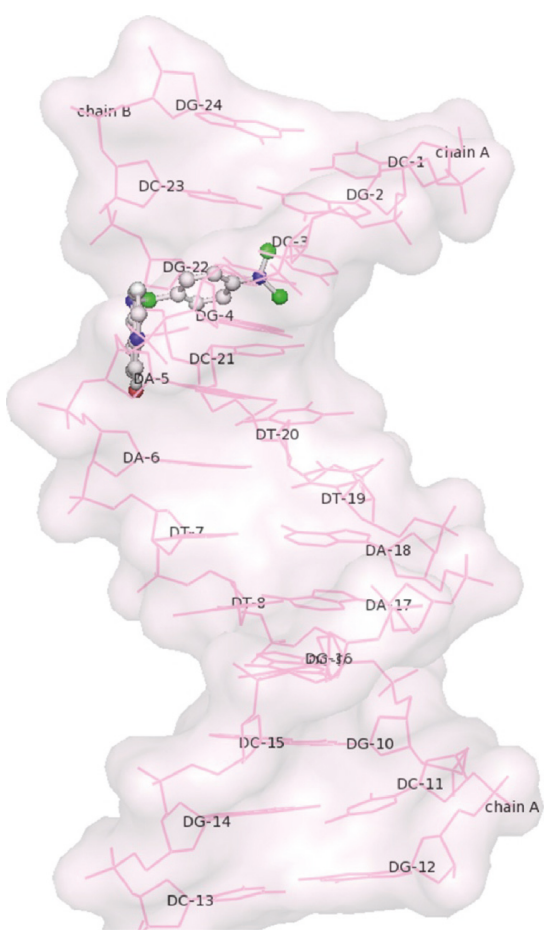

(b)

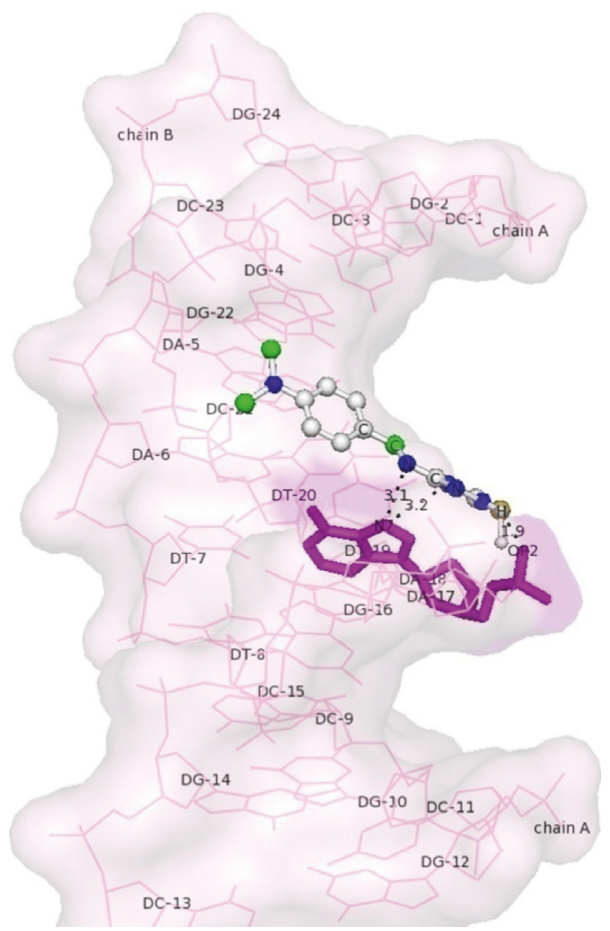

(c)

Figure 6: Molecular docked model of the heterocyclic Schiff base derivatives 3 (a), 4 (b), and 5 (c) with DNA.

were calculated from the graph shown in Figure 7. Higher ability of compound to scavenge the DPPH refers to lower $\mathrm{IC}_{50}$ value. The results show that compounds 1-8 exhibited lowest $\mathrm{IC}_{50}$ value $7.50 \times 10^{-3} \pm 0.007,6.50 \times 10^{-3} \pm 0.008$, $6.20 \times 10^{-3} \pm 0.008, \quad 5.83 \times 10^{-3} \pm 0.008, \quad 8.78 \times 10^{-4} \pm 0.007$, $7.29 \times 10^{-4} \pm 0.006, \quad 5.49 \times 10^{-3} \pm 0.006$, and $6.46 \times 10^{-4} \pm$ $0.007 \mathrm{~mol} / \mathrm{mL}$, respectively $[51,52]$.
3.6.2. Hydrogen Peroxide Scavenging Activity. Hydrogen peroxide was a very reactive species among all the oxygencontaining compounds employed for the investigation of antioxidant activity. UV-vis. spectrophotometer was used to monitor the capability of the target compound to scavenge the hydrogen peroxide. The $\mathrm{IC}_{50}$ values of the compounds 1-8 were found to be $0.88 \pm 0.88,1.16 \pm 0.007,097 \pm 0.007$, 
TABle 2: Antibacterial activity of heterocyclic Schiff base derivatives (1-8) along with experimental "log $P$ ” and the calculated "Clog $P$."

\begin{tabular}{|c|c|c|c|c|c|}
\hline \multirow{2}{*}{ Control } & \multicolumn{3}{|c|}{$\mathrm{MIC}(\mu \mathrm{g} / \mathrm{mL})$} & \multicolumn{2}{|c|}{ Lipophilicity } \\
\hline & Staphylococcus aureus & Escherichia coli & Aspergillus niger & $\log P$ & $\mathrm{Clog} P$ \\
\hline 1 & 200 & 200 & 200 & 3.40 & 3.23 \\
\hline 2 & 150 & 200 & 150 & 2.67 & 2.98 \\
\hline 3 & 125 & 150 & 125 & 4.42 & 4.26 \\
\hline 4 & 50 & 75 & 50 & 3.83 & 4.02 \\
\hline 5 & 50 & 50 & 75 & 3.84 & 4.08 \\
\hline 6 & 125 & 150 & 150 & 4.52 & 4.33 \\
\hline 7 & 125 & 125 & 125 & 2.96 & 3.17 \\
\hline 8 & 50 & 75 & 75 & 3.93 & 4.09 \\
\hline Ofloxacin & 11 & 13.5 & - & - & - \\
\hline Ketoconazole & - & - & 13.5 & - & - \\
\hline
\end{tabular}

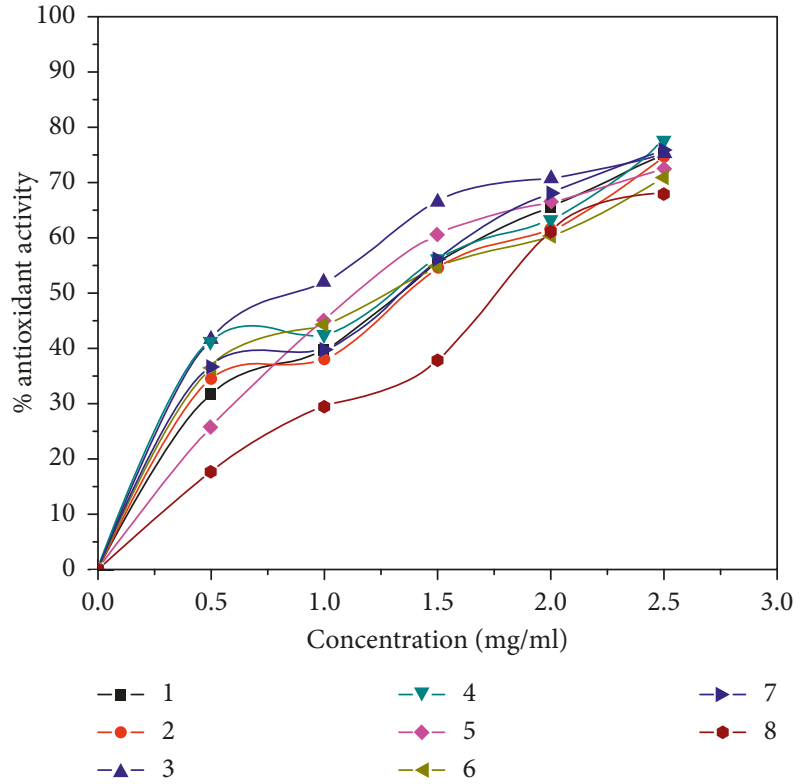

FIGURE 7: DPPH free radical scavenging activity of the heterocyclic Schiff base derivatives (1-8).

$1.04 \pm 0.007,1.08 \pm 0.007,1.11 \pm 0.007,1.02 \pm 0.007$, and $1.31 \pm 0.07 \mathrm{mg} / \mathrm{mL}$, respectively (Figure 8).

\section{Conclusions}

The experimental findings such as hypochromic effect, enhancement in the viscosity, and diminution in the peak current are the significant features of intercalation model. The $K_{\mathrm{b}}$ values were comparable to reported classical intercalators ethidium bromide whose binding constant is of the order of $10^{6}-10^{7} \mathrm{M}^{-1}$. The aforementioned findings in the present work approve the intercalative binding mode of compounds with Ct-DNA. The docking results predict the inhibitory property of 1BNA at molecular level. Heterocyclic Schiff base derivatives $\mathbf{1 - 5}$ showed higher docking score in molecular docking studies among synthesized derivatives with binding energies of $-7.79,-8.47,-7.79,-8.37$, and -8.46, respectively. Further, the in vitro results of

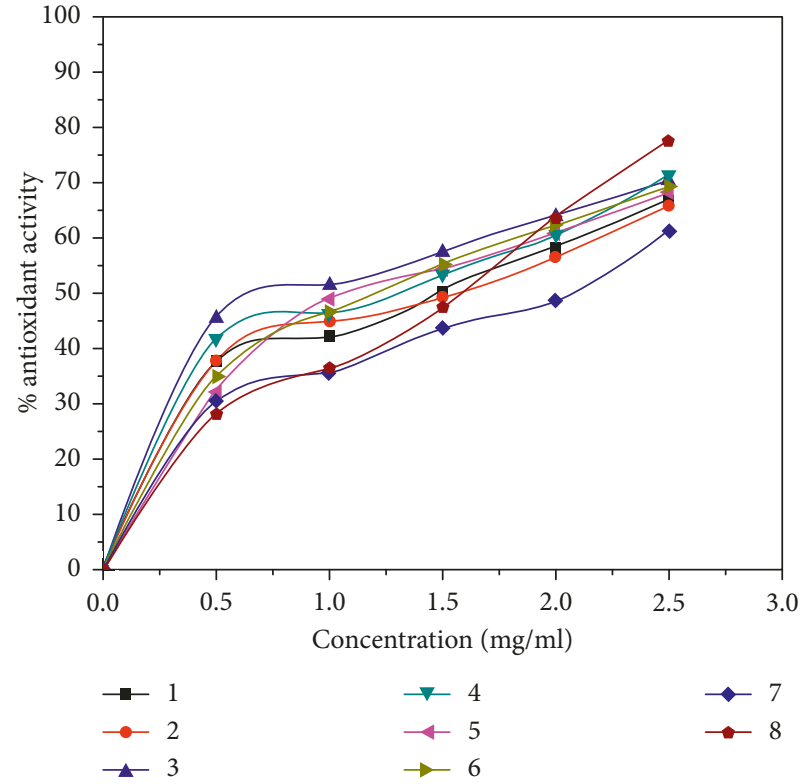

FIGURE 8: Hydrogen peroxide scavenging activity of the heterocyclic Schiff base derivatives (1-8).

compounds 1-5 were found to be better. Therefore, this study could be considered useful for the investigation of new antimicrobial agents.

\section{Data Availability}

The data used to support the findings of this study are included within the article.

\section{Conflicts of Interest}

The authors declare that they have no conflicts of interest.

\section{Acknowledgments}

This research project was supported by a grant from the Research Center of the Female Scientific and Medical Colleges, Deanship of Scientific Research, King Saud University. 


\section{Supplementary Materials}

Figure S1: ${ }^{1} \mathrm{H}$ NMR spectrum of compound 1. Figure S2: ${ }^{13} \mathrm{C}$ NMR spectrum of compound 1. Figure S3: ${ }^{1} \mathrm{H}$ NMR spectrum of compound 2. Figure S4: ${ }^{13} \mathrm{C}$ NMR spectrum of compound 2. Figure S5: ${ }^{1} \mathrm{H}$ NMR spectrum of compound 3. Figure S6: ${ }^{13} \mathrm{C}$ NMR spectrum of compound 3. Figure S7: ${ }^{1} \mathrm{H}$ NMR spectrum of compound 4. Figure S8: ${ }^{13} \mathrm{C}$ NMR spectrum of compound 4. Figure S9: ${ }^{1} \mathrm{H}$ NMR spectrum of compound 5. Figure S10: ${ }^{13} \mathrm{C}$ NMR spectrum of compound 5. Figure S11: ${ }^{1} \mathrm{H}$ NMR spectrum of compound 6. Figure S12: ${ }^{13} \mathrm{C}$ NMR spectrum of compound 6. Figure S13: ${ }^{1} \mathrm{H}$ NMR spectrum of compound 7. Figure S14: ${ }^{13} \mathrm{C}$ NMR spectrum of compound 7. Figure S15: ${ }^{1} \mathrm{H}$ NMR spectrum of compound 8 . Figure S16: ${ }^{13} \mathrm{C}$ NMR spectrum of compound 8. Figure S17: mass spectrum of compound 1. Figure S18: mass spectrum of compound 2. Figure S19: mass spectrum of compound 3. Figure S20: mass spectrum of compound 4. Figure S21: mass spectrum of compound 5. Figure S22: mass spectrum of compound 6. Figure S23: mass spectrum of compound 7. Figure S24: mass spectrum of compound 8. Table S1. Pharmacokinetic parameters important for good oral bioavailability of heterocyclic Schiff base derivatives (1-8). (Supplementary Materials)

\section{References}

[1] P. G. Cozzi, "Metal-Salen Schiff base complexes in catalysis: practical aspects," Chemical Society Reviews, vol. 33, no. 7, pp. 410-421, 2004.

[2] M. Calligaris, G. Nardin, and L. Randaccio, "Structural aspects of metal complexes with some tetradentate schiff bases," Coordination Chemistry Reviews, vol. 7, no. 4, pp. 385-403, 1972.

[3] A. Djouhra, O. Ali, R.-R. Ramiro, and M. Emilia, "A selective naked-eye chemosensor derived from 2-methoxybenzylamine and 2,3-dihydroxybenzaldehyde-synthesis, spectral characterization and electrochemistry of its bis-bidentates Schiff bases metal complexes," Spectrochimica Acta Part A: Molecular and Biomolecular Spectroscopy, vol. 184, pp. 299-307, 2017.

[4] L. Fan, "Synthesis of two coumarin-derived schiff bases and investigation of theirs selectivity for $\mathrm{Zn}^{2+}$," Journal of Fluorescence, vol. 27, no. 4, pp. 1331-1337, 2017.

[5] S.-H. Hsieh, Y.-P. Kuo, and H.-M. Gau, "Synthesis, characterization, and structures of oxovanadium(v) complexes of Schiff bases of $\beta$-amino alcohols as tunable catalysts for the asymmetric oxidation of organic sulfides and asymmetric alkynylation of aldehydes," Dalton Transactions, vol. 1, no. 1, pp. 97-106, 2007.

[6] M. S. Karthikeyan, D. J. Prasad, B. Poojary, K. Subrahmanya Bhat, B. S. Holla, and N. S. Kumari, "Synthesis and biological activity of Schiff and Mannich bases bearing 2,4-dichloro-5fluorophenyl moiety," Bioorganic \& Medicinal Chemistry, vol. 14, no. 22, pp. 7482-7489, 2006.

[7] M. A. Al-Omar and A. E.-G. E. Amr, "Synthesis of some new pyridine-2,6-carboxamide-derived Schiff bases as potential antimicrobial agents," Molecules, vol. 15, no. 7, pp. 4711-4721, 2010.

[8] Y. Ünver, S. Deniz, F. Çelik, Z. Akar, M. Küçük, and K. Sancak, "Synthesis of new 1,2,4-triazole compounds containing Schiff and Mannich bases (morpholine) with antioxidant and antimicrobial activities," Journal of Enzyme Inhibition and Medicinal Chemistry, vol. 31, no. 3, pp. 89-95, 2016.

[9] M. E. Azab, S. A. Rizk, and N. F. Mahmoud, "Facile synthesis, characterization, and antimicrobial evaluation of novel heterocycles, schiff bases, and $N$-nucleosides bearing phthalazine moiety," Chemical and Pharmaceutical Bulletin, vol. 64, no. 5, pp. 439-450, 2016.

[10] A. El-Faham, S. M. Soliman, H. A. Ghabbour et al., "Ultrasonic promoted synthesis of novel $s$-triazine-Schiff base derivatives; molecular structure, spectroscopic studies and their preliminary anti-proliferative activities," Journal of Molecular Structure, vol. 1125, pp. 121-135, 2016.

[11] A. E.-G. E. Amr, N. M. Sabrry, M. M. Abdalla, and B. F. AbdelWahab, "Synthesis, antiarrhythmic and anticoagulant activities of novel thiazolo derivatives from methyl 2-(thiazol-2ylcarbamoyl)acetate," European Journal of Medicinal Chemistry, vol. 44, no. 2, pp. 725-735, 2009.

[12] F. A. Ragab, N. M. Abdel Gawad, H. H. Georgey, and M. F. Said, "Synthesis of novel 1,3,4-trisubstituted pyrazoles as anti-inflammatory and analgesic agents," European Journal of Medicinal Chemistry, vol. 63, pp. 645-654, 2013.

[13] S. F. Mohamed, E. M. Flefel, A. E.-G. E. Amr, and D. N. Abd El-Shafy, "Anti-HSV-1 activity and mechanism of action of some new synthesized substituted pyrimidine, thiopyrimidine and thiazolopyrimidine derivatives," European Journal of Medicinal Chemistry, vol. 45, no. 4, pp. 1494-1501, 2010.

[14] B. Shafaatian, Z. Ozbakzaei, B. Notash, and S. A. Rezvani, "Synthesis, characterization, single crystal X-ray determination, fluorescence and electrochemical studies of new dinuclear nickel(II) and oxovanadium(IV) complexes containing double Schiff base ligands," Spectrochimica Acta Part A: Molecular and Biomolecular Spectroscopy, vol. 140, pp. 248-255, 2015.

[15] H. Zafar, A. Ahmad, A. U. Khan, and T. A. Khan, "Synthesis, characterization and antimicrobial studies of Schiff base complexes," Journal of Molecular Structure, vol. 1097, pp. 129-135, 2015.

[16] Z. Parsaee, "Sonochemical synthesis and DFT studies of nano novel Schiff base cadmium complexes: green, efficient, recyclable catalysts and precursors of Cd NPs," Journal of Molecular Structure, vol. 1146, pp. 644-659, 2017.

[17] M. A. Diab, A. Z. El-Sonbati, A. F. Shoair, A. M. Eldesoky, and N. M. El-Far, "Synthesis, structural, spectroscopic and biological studies of Schiff base complexes," Journal of Molecular Structure, vol. 1141, pp. 710-739, 2017.

[18] F. Ahmadi, A. A. Alizadeh, N. Shahabadi, and M. RahimiNasrabadi, "Study binding of Al-curcumin complex to dsDNA, monitoring by multispectroscopic and voltammetric techniques," Spectrochimica Acta Part A: Molecular and Biomolecular Spectroscopy, vol. 79, no. 5, pp. 1466-1474, 2011.

[19] S. Kashanian, S. Javanmardi, A. Chitsazan, M. Paknejad, and K. Omidfar, "Fluorometric study of fluoxetine DNA binding," Journal of Photochemistry and Photobiology B: Biology, vol. 113, pp. 1-6, 2012.

[20] M. Khorasani-Motlagh, M. Noroozifar, and S. MirkazehiRigi, "Fluorescence and DNA-binding spectral studies of neodymium(III) complex containing 2,2'-bipyridine, [Nd(bpy)2Cl3·OH2]," Spectrochimica Acta Part A: Molecular and Biomolecular Spectroscopy, vol. 75, no. 2, pp. 598-603, 2010.

[21] B.-D. Wang, Z.-Y. Yang, P. Crewdson, and D.-Q. Wang, "Synthesis, crystal structure and DNA-binding studies of the Ln(III) complex with 6-hydroxychromone-3-carbaldehyde 
benzoyl hydrazone," Journal of Inorganic Biochemistry, vol. 101, no. 10, pp. 1492-1504, 2007.

[22] V. G. Vaidyanathan and B. U. Nair, "Synthesis, characterization and electrochemical studies of mixed ligand complexes of ruthenium(II) with DNA," Dalton Transactions, no. 17, pp. 2842-2848, 2005.

[23] K. Tsai, T.-G. Hsu, K.-M. Hsu et al., "Oxidative DNA damage in human peripheral leukocytes induced by massive aerobic exercise," Free Radical Biology and Medicine, vol. 31, no. 11, pp. 1465-1472, 2001.

[24] C. S. Rivas, J. C. Espin, and H. Wichers, "An easy and fast test to compare total free radical scavenger capacity of foodstuffs," Phytochemical Analysis, vol. 11, no. 5, pp. 330-338, 2000.

[25] T. S. Kamatchi, N. Chitrapriya, S. L. Ashok Kumar et al., "The effect of incorporating carboxylic acid functionalities into $2,2^{\prime}$-bipyridine on the biological activity of the complexes formed: synthesis, structure, DNA/protein interaction, antioxidant activity and cytotoxicity," RSC Advances, vol. 7, no. 27, pp. 16428-16443, 2017.

[26] J. K. Barton, A. Danishefsky, and J. Goldberg, "Tri$\mathrm{s}$ (phenanthroline)ruthenium(II): stereoselectivity in binding to DNA," Journal of the American Chemical Society, vol. 106, no. 7, pp. 2172-2176, 1984.

[27] M. Kumar, T. Padmini, and K. Ponnuvel, "Synthesis, characterization and antioxidant activities of Schiff bases are of cholesterol," Journal of Saudi Chemical Society, vol. 21, pp. S322-S328, 2017.

[28] C. M. da Silva, D. L. da Silva, L. V. Modolo et al., "Schiff bases: a short review of their antimicrobial activities," Journal of Advanced Research, vol. 2, no. 1, pp. 1-8, 2011.

[29] A. A.-M. Abdel-Aziz, "Novel and versatile methodology for synthesis of cyclic imides and evaluation of their cytotoxic, DNA binding, apoptotic inducing activities and molecular modeling study," European Journal of Medicinal Chemistry, vol. 42, no. 5, pp. 614-626, 2007.

[30] S. Satyanarayana, J. C. Dabrowiak, and J. B. Chaires, "Neither .DELTA.-nor .LAMBDA.-tris(phenanthroline)ruthenium(II) binds to DNA by classical intercalation," Biochemistry, vol. 31, no. 39, pp. 9319-9324, 1992.

[31] H. Chao, W.-J. Mei, Q.-W. Huang, and L.-N. Ji, "DNA binding studies of ruthenium(II) complexes containing asymmetric tridentate ligands," Journal of Inorganic Biochemistry, vol. 92, no. 3-4, pp. 165-170, 2002.

[32] M. Muralisankar, S. Sujith, N. S. P. Bhuvanesh, and A. Sreekanth, "Synthesis and crystal structure of new monometallic and bimetallic copper(II) complexes with $\mathrm{N}$ substituted isatin thiosemicarbazone ligands: effects of the complexes on DNA/protein-binding property, DNA cleavage study and in vitro anticancer activity," Polyhedron, vol. 118, pp. 103-117, 2016.

[33] T. Kiran, V. G. Prasanth, M. M. Balamurali et al., "Synthesis, spectroscopic characterization and in vitro studies of new heteroleptic copper (II) complexes derived from 2-hydroxy napthaldehyde Schiff's bases and N, N donor ligands: antimicrobial, DNA binding and cytotoxic investigations," Inorganica Chimica Acta, vol. 433, pp. 26-34, 2015.

[34] Z. Asadi, N. Nasrollahi, H. Karbalaei-Heidari et al., "Investigation of the complex structure, comparative DNAbinding and DNA cleavage of two water-soluble mono-nuclear lanthanum(III) complexes and cytotoxic activity of chitosan-coated magnetic nanoparticles as drug delivery for the complexes," Spectrochimica Acta Part A: Molecular and Biomolecular Spectroscopy, vol. 178, pp. 125-135, 2017.
[35] M. Jiang, M. X. Xie, D. Zheng, Y. Liu, X. Y. Li, and X. Chen, "Spectroscopic studies on the interaction of cinnamic acid and its hydroxyl derivatives with human serum albumin," Journal of Molecular Structure, vol. 692, pp. 71-80, 2004.

[36] M. Shakir, S. Hanif, M. F. Alam, M. Farhan, and H. Younus, "Hybrid pharmacophore approach for bio-relevant di-imines based homobimetallic complexes incorporating functionalized dicarboxylates as co-ligands: synthesis, spectral and structural activity dependent biological insights (in-vitro DNA and HSA binding, antioxidant and cytotoxicity)," Journal of Photochemistry and Photobiology B: Biology, vol. 174, pp. 106-125, 2017.

[37] P.-X. Xi, Z.-H. Xu, F.-J. Chen, Z.-Z. Zeng, and X.-W. Zhang, "Study on synthesis, structure, and DNA-binding of Ni, Zn complexes with 2-phenylquinoline-4-carboylhydrazide," Journal of Inorganic Biochemistry, vol. 103, no. 2, pp. 210-218, 2009.

[38] S. Tahir, A. Badshah, R. A. Hussain et al., "DNA-binding studies and biological activities of new nitrosubstituted acyl thioureas," Journal of Molecular Structure, vol. 1099, pp. 215-225, 2015.

[39] M. Iqbal, S. Ali, M. N. Tahir, and N. A. Shah, "Dihydroxobridged dimeric $\mathrm{Cu}$ (II) system containing sandwiched noncoordinating phenylacetate anion: crystal structure, spectroscopic, anti-bacterial, anti-fungal and DNA-binding studies of $\left[(\right.$ phen $)\left(\mathrm{H}_{2} \mathrm{O}\right) \mathrm{Cu}(\mathrm{OH})_{2} \quad \mathrm{Cu}\left(\mathrm{H}_{2} \mathrm{O}\right)($ phen $\left.)\right] 2 \mathrm{~L} .6 \mathrm{H}_{2} \mathrm{O}$ : ( $\mathrm{HL}=$ phenylacetic acid; phen=1,10-phenanthroline)," Journal of Molecular Structure, vol. 1143, pp. 23-30, 2017.

[40] K. Jumbri, H. Ahmad, E. Abdulmalek, and M. B. Abdul Rahman, "Binding energy and biophysical properties of ionic liquid-DNA complex: understanding the role of hydrophobic interactions," Journal of Molecular Liquids, vol. 223, pp. 1197-1203, 2016.

[41] P. J. Lewi, M. de Jonge, F. Daeyaert et al., "On the detection of multiple-binding modes of ligands to proteins, from biological, structural, and modeling data," Journal of ComputerAided Molecular Design, vol. 17, pp. 129-134, 2003.

[42] M. Pulaganti, C. M. Anuradha, and C. S. Chitta Suresh Kumar, "Design, synthesis, and evaluation of pyrazolo-pyrazole derivatives on Methylisocitratelyase of Pseudomonas aeruginosa: in silico and in vitro study," Journal of Biomolecular Structure and Dynamics, vol. 35, no. 11, pp. 2509-2529, 2017.

[43] W. DeLano, The PyMol Molecular Graphics System, W. L. DeLano, San Carlos, CA, USA, 2006.

[44] P. S. Nayab, M. Pulaganti, S. K. Chitta, and Rahisuddin, "Multi-spectroscopic and molecular docking studies on the interaction of new phthalimides withcalf-thymusDNA:In vitrofree radical scavenging activities," Spectroscopy Letters, vol. 49, no. 2, pp. 108-117, 2016.

[45] K. Zhou and L. Yu, "Effects of extraction solvent on wheat bran antioxidant activity estimation," LWT-Food Science and Technology, vol. 37, no. 7, pp. 717-721, 2004.

[46] I. A. Ansari, F. Sama, M. Shahid et al., "Isolation of proton transfer complexes containing 4-picolinium as cation and pyridine-2,6-dicarboxylate complex as anion: crystallographic and spectral investigations, antioxidant activities and molecular docking studies," RSC Advances, vol. 6, no. 14, pp. 11088-11098, 2016.

[47] K. Dhahagani, S. Mathan Kumar, G. Chakkaravarthi et al., "Synthesis and spectral characterization of Schiff base complexes of $\mathrm{Cu}(\mathrm{II}), \mathrm{Co}(\mathrm{II}), \mathrm{Zn}$ (II) and $\mathrm{VO}(\mathrm{IV})$ containing 4-(4aminophenyl)morpholine derivatives: antimicrobial evaluation and anticancer studies," Spectrochimica Acta Part A: 
Molecular and Biomolecular Spectroscopy, vol. 117, pp. 87-94, 2014.

[48] N. Beyazit, D. Çakmak, and C. Demetgül, "Chromone-based Schiff base metal complexes as catalysts for catechol oxidation: synthesis, kinetics and electrochemical studies," Tetrahedron, vol. 73, no. 19, pp. 2774-2779, 2017.

[49] R. Arif, P. S. Nayab, and P. Rahisuddin, "Synthesis, characterization, antibacterial, DNA binding and molecular docking studies of novel $\mathrm{N}$-substituted phthalimides," Heterocycl Letter, vol. 5, pp. 223-239, 2015.

[50] P. S. Nayab, M. Pulaganti, S. K. Chitta, and Rahisuddin, "A new isoindoline based schiff base derivative as $\mathrm{Cu}$ (II) chemosensor: synthesis, photophysical, DNA binding and molecular docking studies," Journal of Fluorescence, vol. 25, no. 6, pp. 1763-1773, 2015.

[51] P. S. Nayab, M. Pulaganti, S. K. Chitta, M. Abid, and R. Uddin, "Evaluation of DNA binding, radicals scavenging and antimicrobial studies of newly synthesized $N$-substituted naphthalimides: spectroscopic and molecular docking investigations," Journal of Fluorescence, vol. 25, no. 6, pp. 1905-1920, 2015.

[52] I. Yousuf and F. Arjmand, "In vitro DNA binding profile of enantiomeric dinuclear $\mathrm{Cu}(\mathrm{II}) / \mathrm{Ni}$ (II) complexes derived from 1-/d-histidine-terepthaldehyde reduced Schiff base as potential chemotherapeutic agents," Journal of Photochemistry and Photobiology B: Biology, vol. 164, pp. 83-95, 2016. 

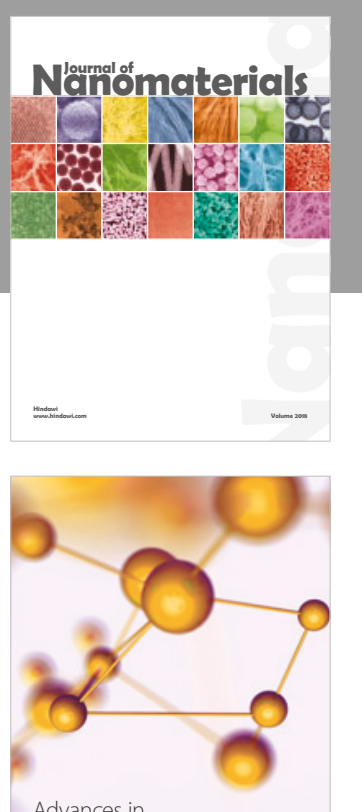

Physical Chemistry
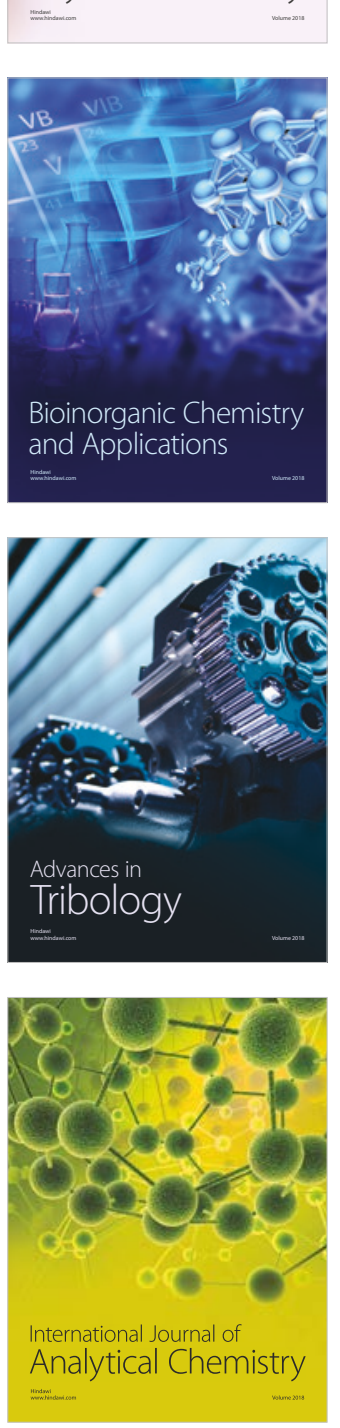

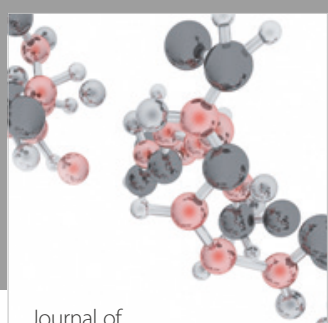

Analytical Methods

in Chemistry

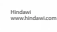

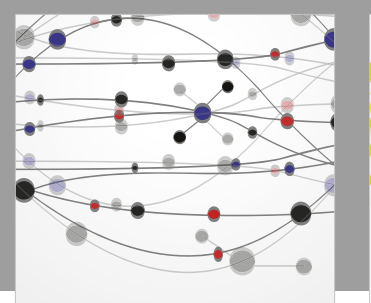

The Scientific World Journal

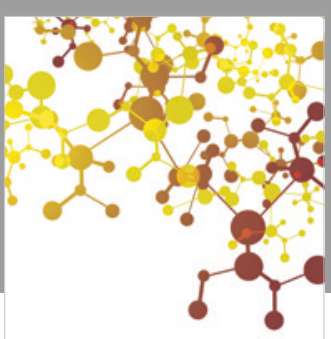

Journal of

Applied Chemistry
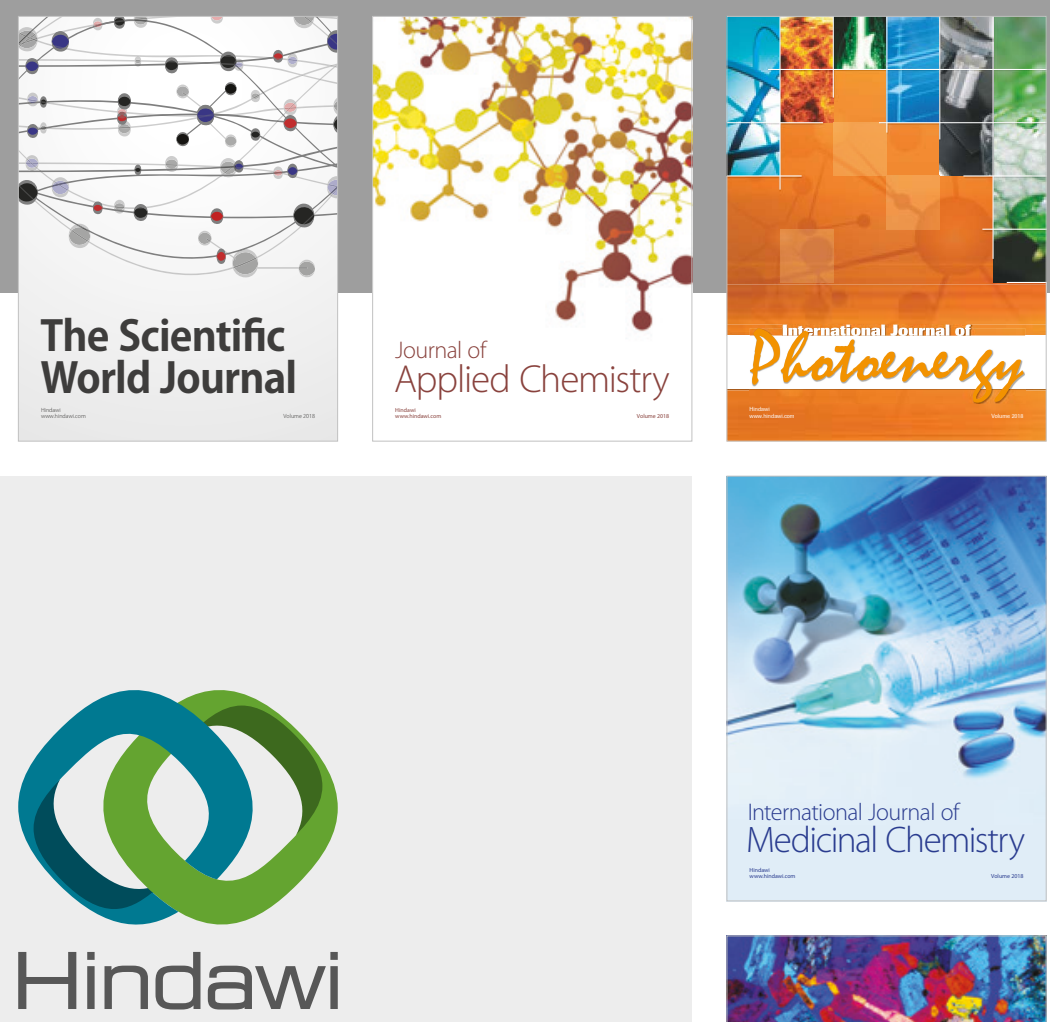

Submit your manuscripts at

www.hindawi.com
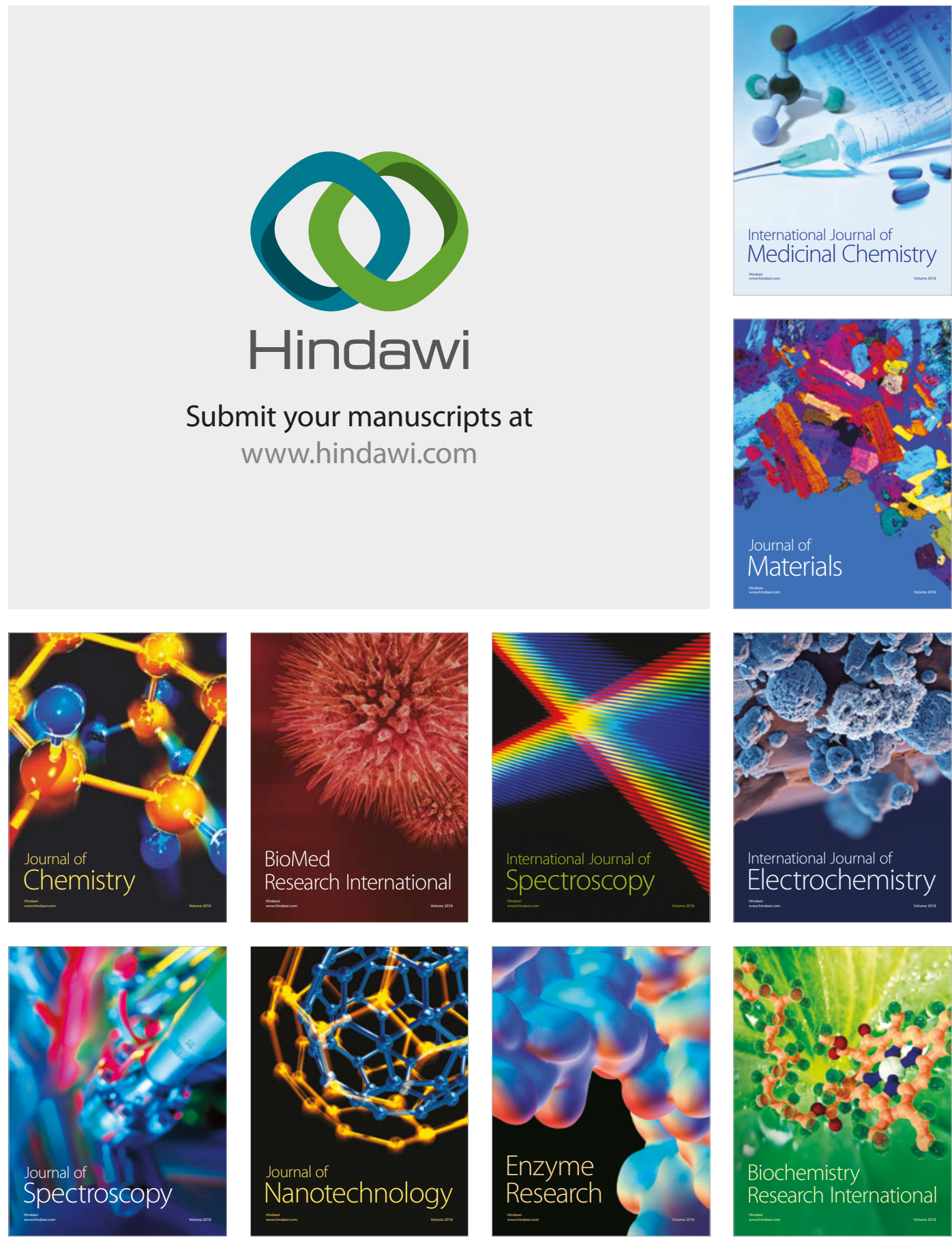
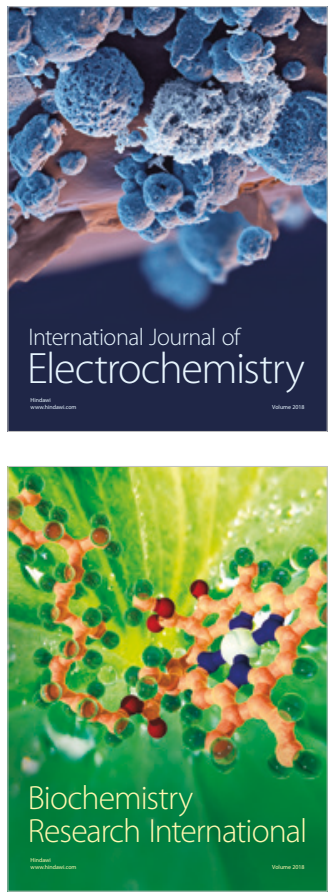